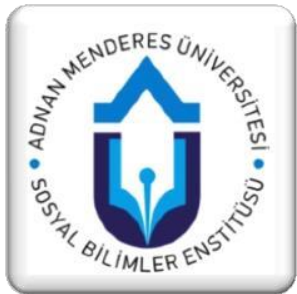

\title{
Yükseköğretimde Etkinlik Analizi: Seçilmiş OECD Ülkeleri Örneği ${ }^{1}$
}

\author{
Sibel SELIM², Ayșe BİÇER ${ }^{3}$, Sibel AYBARÇ4
}

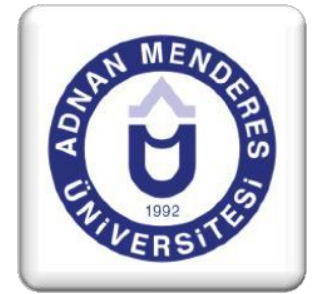

Özet

Küreselleşme ile birlikte bilginin ve teknolojinin hakim olduğu dünyada yeni bir çağ başlamıştır. Bilgi "güç̧" haline gelmiştir. Bundan dolayı içinde bulunduğumuz dönemde bilginin ve bilimin yuvası olan yüksekögretime olan talep artmıştır. Talebi karşılayabilmek için üniversitelere yeni yatırımlar yapılmaktadır. Yatırımların ne derece etkin kullanıldığının tespiti açısından yükseköğretimde performans değerlendirmesi önem arz etmektedir. Bu bağlamda bu çalışmada, 2015 yılı baz alınarak Veri Zarflama Analizi (VZA) ile seçilmiş OECD ülkelerinde hem akademik performansa, hem de eğitime yönelik göstergeler kullanılarak yükseköğretimde etkinliğin ölçülmesi amaçlanmaktadır. Bu amaçla gerçekleştirilen etkinlik analizi kapsamında, akademik performansa yönelik 25 OECD ülkesi ve eğitime yönelik iki farklı veri kümesi ile sırasıyla 24 ve 25 OECD ülkesi benzer girdi kullanan ve çıktı üreten karar verme birimi olarak belirlenmiştir. Analizlerde etkinlik değerleri ile birlikte çıktı değişkenleri açısından etkin olmayan karar verme birimlerinin (KVB) potansiyel iyileştirme oranları hesaplanmıştır. Bu çalışmada akademik performans ve eğitime yönelik etkinlik analizinden elde edilen sonuçlara göre, Türkiye en düşük etkinliğe sahip ülkeler arasında yer almaktadır. Her üç analizde de etkin bulunan ülkeler Finlandiya, İrlanda ve Slovenya'dır.

Anahtar Kelimeler: Yükseköğretim, veri zarflama analizi, teknik etkinlik, OECD

Jel Kodları: C67, I21, I23

Efficiency Analysis in Higher Education: The Case of Selected OECD Countries

\begin{abstract}
With globalization, a new era has begun in the world where knowledge and technology dominate. Knowledge has become "power". Therefore, the demand for higher education, which is the home of knowledge and science, has increased in the current period. New investments are made in universities to meet the demand. Performance evaluation in higher education is important in determining how effectively investments are used. In this context, this study aims to measure efficiency in higher education by using indicators for both academic performance and education in OECD countries selected by Data Envelopment Analysis (DEA) based on 2015. Within the scope of the efficiency analysis carried out for this purpose, 25 OECD countries for academic performance and 24 and 25 OECD countries with two different data sets for education have been determined as decision-making units that use similar inputs and produce outputs. In the analysis, potential improvement rates of inefficiency decisionmaking units (DMU) in terms of output variables have been calculated together with efficiency values. In this study, according to the results obtained from the analysis of the academic performance and educational efficiency, Turkey is among the countries with the lowest efficiency. Efficient countries in all three analyzes are Finland, Ireland and Slovenia.
\end{abstract}

Keywords: Higher education, data envelopment analysis, technically efficiency, OECD

Jel Codes: C67, I21, I23

\footnotetext{
${ }^{1}$ Bu makale, Manisa Celal Bayar Üniversitesi, Sosyal Bilimler Enstitüsü Ekonometri Anabilim Dalı'nda Prof. Dr. Sibel Selim'in danışmanlığında 2019 yılında tamamlanmış olan ve Ayşe Biçer tarafindan savunulan "Yükseköğretimde Etkinlik Analizi: Seçilmiş OECD Ülkeleri Örneği” başlıklı yüksek lisans tezinden türetilmiştir.

${ }^{2}$ Prof. Dr. Manisa Celal Bayar Üniversitesi, İktisadi ve İdari Bilimler Fakültesi, Ekonometri Bölümü, sibel.selim@cbu.edu.tr, ORCID ID: 0000-0002-8464-588X. (Sorumlu yazar)

${ }^{3}$ Ayşe Biçer, response.write@ windowslive.com, ORCID ID: 0000-0002-1117-1564.

${ }^{4}$ Doç. Dr. Manisa Celal Bayar Üniversitesi, Ahmetli Meslek Yüksekokulu, sibel.aybarc@ cbu.edu.tr, ORCID ID: 0000-0002-9756-4923.
} 


\section{Giriş}

Tarih boyunca insanlık, aydınlanma çağı ve sanayi devrimi gibi farklı akımlara şahit olmuştur. İnsanın düşünme eyleminin bir sonucu olarak ortaya çıkan bu akımlardan sonuncusu, bilgi çağıdır. Değişen ve gelişen günümüz koşullarında toplumları ve bireyleri ileri taşıyan bilginin önemi artmıştır. Teknolojinin ve iletişimin güçlenmesi ile bilginin yayılımı da kolaylaştığından bilgi çağı bütün dünyayı sarmıştır.

Eğitim, ömür boyu süren bir öğrenme ve bilgi edinme eylemidir. Ailede başlayan eğitim, özel veya kamu eğitim kurumları aracılığıyla, ilkokul, ortaokul, lise ve yükseköğretim kademelerinde devam etmektedir. Öğrencilere iyi hizmet sunmak, topluma ve refah seviyesine faydalı olmak, bilginin ve bilimin 1şığında yürüyen bireyler yetiştirerek geleceğe katkıda bulunmak eğitim kurumlarının amaçları arasındadır. Eğitimin bireysel faydalarının başında maddi ve manevi ömür boyu kazancın artması gelmektedir. Göreli olarak toplumsal gelirde artış olmakta, daha iyi ve kaliteli bireyler yetişmekte, halk sağılığında ilerlemeler olmakta, demokratikleşmenin gelişmesi sağlanmakta, yoksulluğun ve eşitsizliğin azalması gibi eğitimin toplumsal faydaları sayılabilmektedir (Uysal ve Aydemir, 2016: 276). Bilginin, gelecekteki servet kaynağı olarak maddi sermayenin önüne geçmesiyle birlikte dünya ekonomisi de bir değişim içine girmiştir.

Bilginin önemi arttıkça, eğitim ve özellikle de yükseköğretim de bundan payını almıştır. Yükseköğretim kurumlarında üretilen bilginin kalitesi ve ekonomide kullanılabilirliği, ulusal ve uluslararası rekabet gücü açısından giderek önem kazanmaktadır (Gencel, 2001: 164165). Diplomanın artık beceri isteyen pek çok iş için birincil koşul haline gelmesi nedeniyle ülkeler, daha fazla kişiye yüksek standartlarda eğitim sağlamak zorundadır. Küreselleşme ile birlikte içinde bulunulan bu çağda insana yapılan yatırım en önemli yatırım olarak görülmektedir. Beşeri sermaye olarak adlandırılan bu tasarruflar bireylerin kendilerini geliştirmelerine bağlıdır. İçinde bulunulan koşullarda kendini bilim, teknoloji, eğitim bakımından geliştirmiş gündeme hakim bireyler en ön sıralarda toplumlarının da gelişmesine katkıda bulunmaktadır. Bu nedenle eğitim kurumları, bilgi çă̆ında en çok kendini geliştirmesi gereken kurumlardır. Yükseköğretim bilginin ve bilimin üretildiği temel kurumlardır. Bilgi çağında yükseköğretimin önemi daha da artmış ve yükseköğretime olan talep yükselmiştir. Artan talebi karşılayabilmek için kamu ve özel kuruluşlar, yeni iş birlikleri, yeni yatırımlar yapma yoluna gitmiştir. Her kurum, en iyi hizmeti vermek dışında aynı zamanda kaynaklarını en etkin şekilde değerlendirmeyi amaçlamıştır.

Ülkelerin sunmuş olduğu mal ve hizmetler içinde yer alan yükseköğretim hizmetlerine ulusların büyük gereksinimleri vardır. Çünkü dünya ekonomisinde alanlarında uzman kişilere yönelik talepteki artış dikkate alındığında, sayıları giderek artan öğrencilere teknik beceriler kazandırmak, hızla değişen dünyada ekonomik ve toplumsal yapıların sürekli yenilenmesine olanak tanıyacak bir eğitim sunmak ve bu hizmetlerden yararlanan kalifiye insanları ülke ekonomisinde değerlendirmek bütün ülkeler için önemli olmaktadır (Gencel, 2001: 212). Gelişmiş ülkelerde yükseköğretimdeki “okullaşma oranı" \%50'lerin çok üzerine çıkmış, dolayısıyla üniversite eğitimi lisedeki eğitim gibi normal bir öğretim kademesini tamamlamak şekline dönüşmüştür (Ergün, 2001: 189). Üniversitelerin ana fonksiyonları olan bilginin üretilmesi, aktarılması, yayılması ciddi bir değişim süreci yaşamaktadır. Yükseköğretime olan bu zorunluluk üniversitelerinde kendi aralarında verdiği eğitime göre sınıflandırılmasına, yeni üniversite modellerinin oluşumuna neden olmuştur. Ayrıca bir taraftan artan beklentiler, diğer taraftan azalan kamu kaynakları arasında sıkışan üniversiteler ise, daha fazla özerklik sağlayarak, gelir kaynaklarını artırıp çeşitlendirmek ve daha verimli yönetim modelleri geliştirmek için yeni arayışlara girmişlerdir (YÖK, 2007). 
Yükseköğretim hizmetinde maliyet minimizasyonu ilkesinin uygulanamaması, analiz yaklaşımı olarak çıktı odaklılığın seçimini güçlü kılmaktadır. Bu nedenle, bu çalışma kapsamında yükseköğretim kamu harcamalarının etkinlik analizini gerçekleştirmek için mevcut girdiler ile maksimum çıktıyı elde eden "çıktı odaklı" bir VZA modeli kullanılmıştır.

Literatür incelendiğinde, yükseköğretimin etkinliğini VZA yöntemiyle ölçen birçok çalışmanın olduğu görülmektedir. Bu çalışmalarda, analizlerde ele alınan bazı değişkenler benzerlik de göstermektedir. Ancak literatür araştırması sonucunda bu çalışmanın amacına uygun olarak ele alınan girdi ve çıktı değişkenleri kullanılarak etkinlik analizlerin yapıldığı çalışmalara rastlanmamıştır. Konuyla ilgili olarak literatürde yer alan çalışmalar arasında; Wolszczak Derlacz (2017), 10 Avrupa ülkesi ve ABD'nin aktif olarak eğitim verdiği 500 yükseköğretim kurumunda, VZA ile bir etkinlik analizi gerçekleştirmiştir. Bu çalışma ile benzer olarak, yayın sayısı, akademik personel sayısı ve toplam öğrenci sayısı değişkenleri kullanılmıştır. Joumady ve Ris (2005)'de VZA ile 8 Avrupa ülkesinin (bu çalışmanın da KVB arasında olan İtalya, İspanya, Fransa, Avusturya, Almanya, Hollanda, İngiltere, Finlandiya) yükseköğretim performansını ölçen bir çalışma yapılmıştır. Agasisti (2009), yükseköğretim kamu harcamaları payının azaltılması durumunda performans ve etkinliğin pozitif yönde etkileneceğini ileri sürmüştür. Toth (2009), VZA ile aralarında Türkiye'nin de yer aldığı toplam 19 Avrupa ülkesini incelemiş ve yükseköğretim hizmetine aktarılan kamu kaynaklarında meydana gelecek artışın etkinlik skorlarını azaltacağı bulgusuna ulaşmıştır.

Bu çalışmada, yükseköğretimin öneminden yola çıkılarak literatürde ilk defa 2015 yılında Türkiye'nin de içinde bulunduğu seçilmiş OECD ülkeleri için yükseköğretimde hem akademik performansa hem de eğitime yönelik etkinlik analizleri gerçekleştirilmiştir. Çalışmanın yöntemi olan VZA kapsamında KVB sayısı ve elde edilen sonuçların tutarlılığ gözetilerek, girdi ve çıktı değişken sayısının belirlenmesi nedeniyle, eğitime yönelik etkinliğin elde edilmesinde iki farklı analiz gerçekleștirilmiștir. Ele alınan bu çalışma, dünya halklarının refahını ve ekonomik kalkınmasını sağlamayı amaçlayan OECD ülkelerinde yükseköğretimin önemi ve ele alınan değişkenlerle etkinlik analizi sonucunda seçilmiş OECD ülkelerinin karşılaştırılması açısından literatüre katkı sağlayacaktır.

$\mathrm{Bu}$ çalışmanın izleyen bölümleri şu şekildedir: İkinci bölümde OECD ülkelerinde eğitim sistemi ele alınmıştır. Üçüncü bölümde yükseköğretimde etkinliğin ölçülmesine yönelik literatür araştırması ve. dördüncü bölümde kullanılan metodoloji sunulmuştur. Analizlerde kullanılan verilerin, değişkenlerin ve bulguların açıklandığı beşinci bölümün ardından bulguların tartışıldığı Sonuç bölümü yer almaktadır.

\section{OECD Ülkelerinde Yükseköğretim}

Türkiye'nin de kurucu üyelerinden olduğu OECD, ekonomik kalkınmanın, içinde bulunulan küreselleşme çağında beşeri sermayeye, bilgiye, dolayısıyla eğitime dayalı olduğunu kabul etmektedir. Bu nedenle üye olan ülkelerdeki eğitim faaliyetlerini belli kriterlere, yaptığı anket ve çalışmalara göre istatistikî olarak belirlemekte; hangi ülke hangi konuda geri kalmışlık gösteriyorsa o ülke için çözüm önerileri sunmakta ve gelişimine yardımcı olmaktadır. Çözüm sürecinde, veri toplama, analiz, müzakere, müşterek karar alma, uygulama, grup baskısı ve çoklu gözlem sırası izlenmektedir.

OECD'nin "Education at a Glance" (2018) adlı raporunda ailelerin sosyal yapısının eğitimdeki başarıda önemli rol oynadığı bir kez daha ortaya konulmuştur. İlköğretim öncesi anaokulu eğitiminin de çocukların ilerleyen yaşlarda başarılı olmasında önemli bir faktör olduğu gözler önüne serilmiştir. OECD, üye ülkelere okul öncesi eğitime daha fazla yatırım yapmaları çağrısında bulunurken, ailelerin yaşadığı sosyal ve ekonomik zorlukların da çocuklarının eğitimdeki başarısında olumsuz etki yaptığını hatırlatmış ve 
eğitimde firsat eşitliğine önemle dikkati çekmiştir. OECD, bu amaçla toplumda ekonomik sosyal sorunlar yaşayanlara ayrılacak fon ve kaynağın önemine işaret etmiştir (OECD, 2018). OECD ülkelerinde 25-34 yaş grubundaki kadınların ortalama \%50'sinin erkeklerin ise \%38'inin yüksek eğitimli olduğunun belirtildiği raporda, lise eğitimi olmayan 25-34 yaş grubundakilerin ülkelere göre oranları da paylaşılmıştır. Bu yaş grubundaki kadınların \%70'inin lise eğitiminin olmadığı Hindistan birinci sırada yer alırken, Türkiye'deki 25-34 yaş arasındaki kadınların \%30’unun eğitim dışı kaldığı ifade edilmiştir (Bıldırcın, 2018). OECD içinde üst orta dereceli eğitimi tamamlayamayan genç kadınların \%45'i iş bulma imkânına sahiptir. Bu oran, genç erkeklerde ise \%71'dir. OECD ülkeleri içinde üst orta dereceli eğitimi bitiremeyen genç kadınların yarıdan azı yine de iș imkânı bulmaktadır. Üst orta dereceli eğitimi tamamlayamayan genç kadınların Türkiye'de dörtte biri, ancak iş bulabilmekte iken, Türkiye bu sıralamada sonuncu sırada yer almaktadır. OECD raporuna göre, eğitim almayan bireylerin özellikle kadınların istihdam oranlarının daha düşük olduğu ortadadir (OECD, 2018).

Batı ülkelerinin aksine, Türk üniversiteleri daha önce var olan medreselerin evrimi ile değil, bilakis bu kurumlara ikame etmek üzere Batı'dan olduğu gibi alınarak kurulmuş kurumlardır (Gürüz, 2003: s. 299). Yeni düzenlemelerden sonra halkın yükseköğretime olan ilgisi artmıştır. Dünyada yaşanan yeni gelişmeler ve reformlardan sonra eğitimin her alanda başrol oynaması yükseköğretime yönelik talep artışını da tetiklemiştir. Hükümetler de bu talep artışını karşılayabilmek, ülkenin refah seviyesini yükseltebilmek için yükseköğretim kurumlarına yatırımlar yapmakta ve gerekli destekleri sağlamaktadır.

Yükseköğretime yönelik talep artışı, aşağıda sıralanan faktörler nedeniyle devam etme eğilimindedir (Kavak, 2011: 57):

- İlköğretimden ortaöğretime geçiş oranları, hafif de olsa yükselmeye devam etmektedir,

- Ortaöğretimde okullaşma oranları ve mezun sayıları artmaya devam etmektedir,

- Yükseköğretime yönelik yetişkin talepleri giderek artmakta ve yaş yelpazesi genişlemektedir,

- Yükseköğrenim görmeye ilişkin sosyal talepteki artış eğilimi (öğrenen toplum) devam etmektedir,

- Yükseköğretimin bireysel faydaları önemini korumaktadır. Bu bağlamda, istihdama katılım, göreli kazançlar ve bireysel getiriler yükselme eğilimindedir,

- Kızların yükseköğretime katılım oranı, erkeklerin katılımından daha hızlı artmaktadır.

Bu eğilimlere bakıldığında, yükseköğretime olan talebin daha da artacağ1 görülmektedir. Ancak önemli olan bu talebin arzını karşılayabilmektir. Üniversiteye olan talep artışından dolayı, yeni sorunlar ortaya çıkmış ve buna istinaden yeni bir kanun çıkarılmıştır.

2547 sayı1ı Yükseköğretim Kanunu ${ }^{5}$ ve Yükseköğretim Kurumları Teşkilatı Hakkında 41 sayılı Kanun Hükmünde Kararname ${ }^{6}$ yürürlüğe girdikten sonra Türk eğitim sistemi içindeki üniversite-akademi ikiliği ortadan kaldırılmış; değişik bakanlıklara bağlı yüksekokullar ve konservatuarlar üniversitelerin çatısı altında toplanmış; yükseköğretim kurumları arasındaki planlama, koordinasyon ve eğitim programlarında asgari müştereklik sağlanarak, sürtüşme ve benzeri sorunlara son verilmiştir (Doğramac1, 2007: 25).

\footnotetext{
${ }^{5}$ 6/11/1981 Tarih ve 17506 Sayılı Resmi Gazete.

${ }^{6}$ 20/07/1982 Tarih ve 17760 Sayılı Resmi Gazete.
} 
1982 Anayasası'nın 130. ve 2547 say1lı yasanın 4. maddesindeki üniversitenin ișlevlerine bakıldığında, dünyadaki diğer üniversiteler gibi Türk üniversiteleri için de "eğitim-öğretim", "bilimsel araştırma" ve "topluma hizmet"in amaçlandığı görülmektedir. Bugün üniversitelerimizde "eğitim öğretim" ve "bilimsel araştırma" işlevleri iç içe birbirine girmiş durumdadır (Erdem, 2005: 78).

\section{Yükseköğretimde Etkinliğin Ölçülmesine Yönelik Literatür Araştırması}

Literatürde yükseköğretim etkinliğini konu alan pek çok çalışma bulunmaktadır. Dünyada yaşanan küreselleşme ve bilgi çağıyla birlikte yükseköğretime verilen önem artmış, dolayısıyla yükseköğretim kurumlarının performansları ve etkinliğinin karşılaştırılabilmesi, etkinlik skorlarının iyileştirilebilmesi açısından gerekli hale gelmiştir.

Jamison ve Lumsden (1975), yükseköğretimde etkinliği araştırmışlardır. Bu çalışmalarında aynı zamanda televizyonun yükseköğretimdeki verimliliği ne ölçüde arttırabileceği konusu da ele alınmıştır. Araştırmada, 180 öğrenciden sadece 50'si tutumların yer aldığı ankete katılmıştır. Analiz sonucunda, tüm ders sunum yöntemlerinin öğrenme ekonomisi açısından eşit derecede etkili olduğu, tartışma oturumlarındaki eğitmenlerin öğrenci tutumlarını açıklamada anlamlı değişkenler olmadığı, Avrupalı öğrenciler ile ders ve eğitime daha yüksek oranda katılan öğrencilerin olay analizlerinde daha yüksek puan aldığı ortaya konulmuştur. Hoenack (1982), yükseköğretimde fiyatlandırma ve etkinlik üzerine ilk çalışmalardan birini gerçekleştirmiştir. Hoenack'a göre etkinlik; fakülte, personel ve öğrenci zamanı, ekipman ve fiziki olanaklar gibi yükseköğrenimde kullanılan kaynaklardan topluma maksimum toplam fayda sağlanmasıdır. Çalışmasında bu faydanın sağlanıp sağlanmadığını ve fiyatlandırmanın etkinliği nasıl etkilediğini göstermeyi amaçlamıştır. Sonuç olarak, fiyatlandırmadan toplumun büyük bir bölümünün etkilendiği ve onların faydaları için fiyatlandırma yapılması gerektiği ortaya çıkmıştır. Tuijman (1990), İsveç üniversitelerinin 1990'lı yıllara kadar olan, kalite ve etkinliğini değerlendirmiştir. Analizinde üç önemli kriter belirlemiştir. Birincisi, farklı geçmişlere sahip öğrencileri kabul etmenin eşitlik ilkesine etkisi; ikincisi, sistemin alt ve lisansüstü seviyelerinde insan kaynağını kullanma ve eğitme etkinliği ve üçüncüsü, araştırma ve geliştirme konusundaki kamu harcamalarına ilişkin bilimsel çalışmaların geliştirilmesi şeklindedir. Çalışmada 9 OECD ülkesi seçilmiş ve baz yıl olarak, 1981-1985 aralığı alınmıştır. Sonuçta, İsveç'teki yükseköğretimli öğrencilerin ölçülen verimi, düşük bulunmuştur. Johnes (1996), İngiltere'de yükseköğretimde performans değerlendirmesini amaçlamıştır. 1980'lerde İngiltere üniversite sektörü tarafından karşılanacak finansal kısıtlar, karar almaya yardımcı olmak için performans göstergelerinin geliştirilmesine duyulan ihtiyacı arttırmıştır. $\mathrm{Bu}$ gerekçeyle yapılan araştırmada, performansın kazanc1-karlılığı etkilediği ve bu nedenle performans göstergelerinin değerlendirilmesi ve dikkate alınması gerektiği belirtilmiştir. McMillan, (1998)'de bilgi çağının yeni başladığı yıllarda yaptığı çalışmada, uzun yıllardır öğrencilere hizmet veren, Kanada üniversitelerinin etkinliğini konu almıştır. Çalışmada 45 adet Kanada üniversitesini karar verme birimi olarak alınmıştır. Çalışmanın uygulama yöntemi olan VZA sonucunda, Kanada'da üniversitelerin yaklaşık \% 94'ü etkin bulunmuştur. Aypay (2006), üniversitelerde akademik etkinlik ve örgütsel davranış arasındaki ilişkiyi inceleyen bir çalışma yapmıştır. Türkiye'deki üniversitelerden yansız olarak seçilen 16 üniversite belirlenmiştir. Belirlenen üniversitelerin Fen Edebiyat Fakülteleri'nin Biyoloji, Kimya, Matematik, Tarih, Fen, Fizik, Sosyoloji ve İktisadi ve İdari Bilimler Fakülteleri'nin Ekonomi bölümlerinde görev yapan yaklaşık 100 öğretim elemanına ait veriler elde edilmiştir. Öğretim üyelerinin akademik etkinliklerinin cinsiyete göre karşılaştırılması sonucu, öğretim üyelerinin akademik etkinliklere katılmalarında anlamlı bir fark bulunamamıştır. 
Dikmen (2007), veri zarflama analizi ile üniversitelerin etkinliğinin ölçülmesine yönelik bir araştırma gerçekleştirmiştir. Uygulamada, VZA'nın 4 modeli uygulanmıştır. Uygulamaya konu olan Türkiye'de 2000-2001 yıllında eğitim veren 51 devlet üniversitesinin, benzer girdileri kullanarak benzer çıktıları üreten karar birimleri oldukları varsayılmış ve üniversitelerin seçimi bu varsayıma dayandırılmıştır. Sonuçta, yükseköğretim kurumlarında yüksek seviyede aylak bir kullanım olduğu ortaya çıkmıştır. Model çözüm sırasına göre, üniversitelerin \% 71, \% 78, \% 94 ve \% 92'sinin etkin olmadığ belirlenmiştir. Kutlar ve Babacan (2008), Türkiye'deki kamu üniversitelerinde CCR (Charnes-Cooper-Rhodes) Etkinliği-Ölçek Etkinliğini VZA uygulaması ile gerçekleştirmişlerdir. 53 devlet üniversitesinin karar verme birimi olarak seçildiği çalışmada, söz konusu karar verme birimlerine ait gözlemlenmiş 8 girdi ve 6 çıktı kullanılarak, analizler beş yıl için yapılmıştır. Elde edilen sonuçlara göre, Türk üniversitelerinde etkinsizlik, sayısal olarak gittikçe artmaktadır. Yapılan çalışmada, kamu kaynaklarının etkin olarak kullanılmadığının açıkça ortada olduğu belirtilmiştir. Kantabutra ve Tang (2010), Tayland kamu üniversitelerinin verim açısından performansını VZA kullanarak incelemektedir. Araştırmada, stokastik sınır yaklaşımı ile veri zarflama analizinin karşılaştırması yapılmış ve VZA stokastik sınır yaklaşımından üstün bulunmuştur. Çalışma, 4 özerk üniversite dâhil, toplam 22 üniversiteyi kapsamaktadır. Çalışmanın sonucunda, özerk devlet üniversitelerinin araştırma verimliliği açısından daha iyi performans gösterdiği görülmüştür. Kuah ve Wong (2011), üniversitelerin etkinliğini araştırmışlardır. İlk olarak çalışmada üniversite performans ölçümü için girdiler ile çıktılar tanımlanmış ve üniversitelerin göreceli öğretim ve araştırma etkinliklerini birlikte değerlendirmek için bir VZA modeli sunulmuştur. Öğretim etkinliği ve araştırma etkinliği, ayrı ayrı analiz edilmiştir. VZA sonuçları, örneklemin az olmasından dolayı, etkin veya etkin olmayan üniversiteleri ayırabilmesi bakımından yetersiz görülmüştür. Ancak çalışma, önceki araştırmalara ek, yeni değişkenleri de (patent ve ödül sayısı gibi) analize dahil etmesi bakımından önemli bulunmuştur.

Aybarç Bursalığlu (2013), yükseköğretime yönelik kamu harcamalarının etkinlik analizini karşılaştırmalı olarak incelemiştir. Çalışmada, mikro ve makro ölçekte ele alınmıştır. Mikro ölçekte, Türkiye'de faaliyet gösteren $51 \mathrm{kamu}$ üniversitesi, makro ölçekte ise seçilmiş $A B$ üyesi ülkeler ile Türkiye'nin yer alıdığı 21 ülkeden oluşan gözlem kümesi çerçevesinde VZA ile yükseköğretimde etkinlik analizi ve ardından Tobit regresyon model ile kamu harcamalarının etkinliği belirlemedeki önemini ortaya konulmuştur. VZA modelleri arasında yer alan çıktı odaklı BCC Modeli (Banker-Charnes-Cooper) çerçevesinde analiz yapılmıştır. Bulgulara göre, Danimarka, Estonya, Finlandiya, İtalya, Portekiz, Slovenya ile Birleşik Krallık tam etkin olan ülkeler arasında iken, en düşük etkinlik skoruna (0.856) sahip ülke Türkiye'dir. Ayrıca, AB üyesi ülkeler ile Türkiye'de yükseköğretime aktarılan kamu kaynaklarının etkinlik skoruna etkileri de Tobit Regresyon modeli ile incelenmiştir. Bu analiz sonucunda ise öğrenci başına kurumsal harcamaların, etkinlik skorlarını pozitif yönde etkilediği, yükseköğretim kurumlarının kaynakları arasında yer alan kamu kaynaklarının etkinlik skorlarını negatif yönde etkilediği ortaya konulmuştur. Aybarç Bursalığlu ve Selim (2015), yükseköğretimde etkinliği belirleyen faktörleri incelemişlerdir. Analizde kullanılan 17 adet AB ülkesi ve Türkiye KVB olarak seçilmiştir. Yapılan VZA ve Tobit Regreyon sonucuna göre, yükseköğretim kamu harcamalarının Gayrisafi Milli Hasıla’ya (GSMH) oranı, akademisyen başına düssen öğrenci sayısı ve akademisyen sayısı arttıkça, etkinlik skorları negatif yönde etkilendiği, yükseköğretim mezunlarının istihdam oranı, yükseköğretim mezunlarının toplam nüfusa oranı ve yükseköğretimli bireylerin yaşam memnuniyeti arttıkça etkinlik skorlarının pozitif yönde etkilendiği görülmüştür. Selim ve Aybarç Bursalıoğlu (2015), 2006-2010 yılları için Türkiye'de 51 kamu üniversitesi için iki aşamalı VZA kullanılmıştır. İlk aşamada üniversitelerin etkinlikleri, bootstrap yönteminin 
kullanıldığı VZA ile elde edilmiştir. İkinci aşamada ise tesadüfü etkiler, Tobit model kullanılarak üniversitelerin etkinliğini belirleyen faktörler ele alınmıştır. Çalışmadan elde edilen bulgulara göre, 2006 yılında Türk kamu üniversitelerinin \% 37'si, 2007'de \% 39, 2008 'de \% 47, 2009'da \% 35 ve 2010'da \% 37'si etkin bulunmuştur.

Hai vd. (2017), üniversite eğitim kaynaklarını bilimsel ve etkin bir şekilde tahsis etmek ve eğitim kaynaklarının verimliliğini arttırmak için üniversite eğitiminin etkinliğinin değerlendirilmesi gerektiğini vurgulamışlardır. Ancak, üniversite verimliliğinin kapsamlı bir şekilde değerlendirilmesi çok amaçlı, çok kısıtlı, çeşitlendirilmiş ve çok seviyeli bir karmaşık sistem olduğunu da savunmuşlardır. Kurguladıkları modelde sadece karar vericilerin tercihlerini değil aynı zamanda diğer bileşenleri de objektif olarak değerlendirmişlerdir. Çalışmada DELPHI, AHP ve VZA yöntemleriyle değerlendirme sunulmaktadır. Örneklem olarak benzer ölçekte toplam 14 üniversite seçilmiş ve çalışmada önerilen kombinasyon modeli 14 üniversitenin etkinliğini değerlendirmek için kullanılmıștır. Üç yöntem kullanılması dolayısıyla yöntemlerin de karşılaştırması yapılmış ve VZA yönteminin daha iyi bir yöntem olduğu sonucuna varılmıştır.

Torre vd. (2017), üniversitelerin etkinlik puanları için bilgi transferinin ilgi düzeyini, İspanya kamu yükseköğretim sistemi üzerine ampirik bir yaklaşım ile incelemişlerdir. İncelemede yükseköğretimin özelliklerini dikkate alarak oluşturulan Bilgi Aktarımı (KT) göstergelerinin yükseköğretim sektöründeki verimlilik analizlerini nasıl etkilediği konu alınmıştır. Okulların performanslarını değerlendirirken KT göstergelerinin uygun olup olmadığını test etmek için mevcut akademik y1l için faaliyette bulunan 50 üniversiteden, 47 İspanyol devlet üniversitesine farklı özelliklere sahip çeşitli veri zarflama analiz modelleri uygulanmıştır. Analizler, homojen verimlilik bulguları gösteren çalışmaların aksine bir sonuç vermiştir. 2014 yılı teknik verimliliğindeki yüksek heterojenlik, farklı üretim yapılarına sahip üniversitelerin farklı tepki gösteren bir sonucu olabileceği incelemede belirtilmiştir. Elde edilen sonuçlar, KT göstergelerinin verimlilik analizlerine dahil edilmesinin etkisinin özelliklerine göre üniversiteden üniversiteye değiştiğini göstermiştir. Wolszczak Derlacz (2017), yükseköğretimde verimliliği ele aldıkları çalışmada, VZA ile Avrupa ve ABD'deki yükseköğretim kurumlarının karşılaştırılması amaçlanmıştır. Toplanan verilerle VZA yöntemi uygulanmış ve karşılaştırma yapılmıştır. Avrupa ülkeleri ve Amerika yükseköğretim kurumları sayısının teknik etkinliği on yıl boyunca değerlendirilmiştir. Sonuçlar, hem kişi başına bölgesel Gayrisafi Yurtiçi Hasıla (GSYIH), hem de bölüm sayısı ile kurumun verimliliği arasında pozitif bir ilişki olduğunu göstermiştir. Ayranc1 (2018), yükseköğretimde etkinlik ve eşitlik için yapılan reformları, Türkiye'nin de içinde bulunduğu bazı OECD ülkelerine göre değerlendirmiştir. Çalışma, Türkiye'nin OECD ülkeleri arasında nerede olduğunu göstermesi bakımından önem arz etmektedir. Çalışmada, 20 OECD ülkesinin 1998-2012 yılları arasında yükseköğretim sistemlerinin Toplam Faktör Verimliliği (TFV) değişimi VZA ile analiz edilmiştir. Yükseköğretim sisteminde reform yapan ülkelerin TFV değişim endeks bileşenlerinden olan teknolojik değişim endeks değerlerinde artış gerçekleştiği, reformların yapıldığı ilk yılda teknik etkinlik değişim değerlerinde geçici bir düşüşün meydana geldiği, ancak yapılan reformun sisteme entegre olması ile birlikte teknik etkinlik değişim değerlerinin tekrar yükselmeye başladığı kanıtlanmaktadır.

Yang vd. (2018), Çin'deki araştırma üniversitelerinin etkinliğini ele almışlardır. Çalışma, VZA yöntemi ile 64 Çin araştırma üniversitesinin verimliliğini ve 2010-2013 dönemindeki evrimini araştırmaktadır. Araştırmada, 2010-2013 yıllarına ait veriler kullanılarak, 64 araştırma üniversitesi KVB seçilmiştir. AR-GE fonları, öğretim ve araştırma personeli ve devlet blok fonları girdi olarak, SCI / SSCI yayınlarının sayısı, toplam öğrenci sayısı (doktora adayları, yüksek lisans öğrencileri ve lisans öğrencileri dahil), toplam patent sayısı 
(patent başvuruları ve yetkili patentler dahil) ve diğer fikri mülkiyet formlarının sayısı (örneğin, yazılım telif hakları) çıktı değişkenleri olarak belirlenmiştir. Ardından iki ağlı bir VZA modeli geliştirilmiş ve veriler analize tabi tutulmuştur. Ampirik sonuçlar, 64 üniversitenin ortalama etkinliğinin incelenen 2010- 2013 döneminde arttığını göstermiştir. Bununla birlikte, teknolojideki değişmelerin ilk dönemlerdeki negatif etkisi üniversitelerdeki verimlilikleri de düşürmüştür. Güran ve Ayrancı (2019), 2000-2012 dönemine ilişkin 21 OECD ülkesine ait yükseköğretim sisteminin toplam faktör verimlilik değişimini, Malmquist Toplam Faktör Verimlilik Endeksi aracılığıyla analiz etmiştir. Çalışmada ülkelerin teknik etkinlik, saf teknik etkinlik, ölçek etkinlik ve teknolojik değişim değerleri hesaplanarak toplam faktör verimlilik değişimlerinin kaynakları belirlenmiştir. Analiz bulgularına göre; 21 OECD ülkesinin 2000-2012 dönemi ortalama değerlerine göre toplam faktör verimlilik değişim endeks değerlerinde en büyük artışı kaydeden ülkeler Avustralya, Amerika ve Norveç iken, en büyük azalış Yeni Zelanda, Çek Cumhuriyeti ve Türkiye'de görülmüştür.

\section{Veri Zarflama Analizi}

VZA, çok sayıda değişken ve ilişkilerin bir arada değerlendirildiği "matematiksel programlama" gibi teknikleri kullandığı için çok sayıda girdi ve çıtının bir arada değerlendirilmesine olanak vermeyen ve karar vericiyi sınırlandıran diğer tekniklere nazaran, kullanıcıya daha rahat çalışılabilme imkânı sunmaktadır. Çünkü politika üretilen ve yönetimsel kararların alındığı gerçek hayat problemleri, pek çok faktörün aynı anda değerlendirilmesini gerektiren karmaşık bir yapıya sahiptir. VZA, yol gösterici analizlerin ve yorumların yapılabilmesine olanak sağlamaktadır (Akan ve Çalmaşur, 2011:17). Veri Zarflama Analizi, çıktıların ağılıklı toplamının girdilerin ağırlıklandırılmış toplamına bölümüdür. VZA'nın etkinlik ölçüm formülü genel olarak şu şekilde ifade edilir;

$\frac{u_{1} y_{1}+u_{2} y_{2}+\cdots+u_{n} y_{n}}{v_{1} x_{1}+v_{2} x_{2}+\cdots+v_{m} x_{m}}$

Denklem (1)'e göre, etkinliği belirlenmek istenen karar noktası için n adet çıktı ve m adet girdi vardır. Burada, $u_{n}$ n. çıktının ağırlığını, $y_{n}$ n. çıtının miktarını, $v_{m}$ m. girdinin ağırlığını ve $x_{m} \mathrm{~m}$. girdinin miktarını göstermektedir.

Şekil 1'de VZA'nın Toplam Etkinlik (TE) sınırları verilmiştir. Şekil 1'de görüldüğü gibi, VZA'da bir etkinlik sınırı belirlenmektedir ve bu sınır üzerindeki noktalara etkin KVB denilmektedir. Sınır üzerinde olmayan KVB'ler etkin değildir. Bu noktalar için kısıt 0'dan küçük ve 1'den büyük olamamalarıdır. Etkinliğin bir koşulu da en az girdi ile en çok çıtıy1 üretmektir. En az girdi kullanıp, en fazla çıktı üreten KVB'ler en iyi performansa sahip olan noktalardır. Bu noktaların etkinlik seviyesi, 1'e eşittir. 


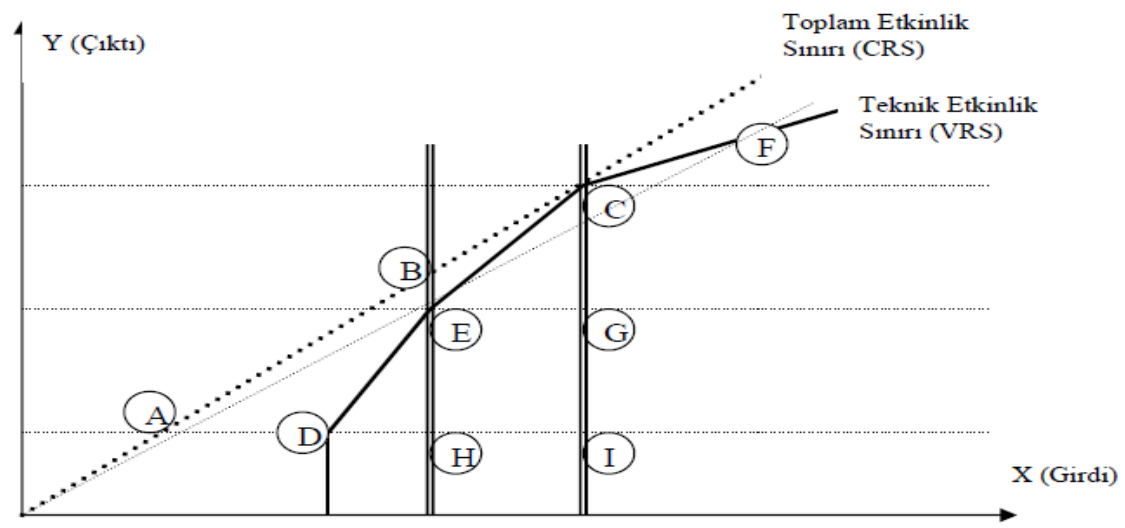

Şekil 1: Veri Zarflama Analizinin Grafiksel Gösterimi

Kaynak: Bay, 2009: 70.

\subsection{VZA Modelleri}

VZA yöntemi ilk kez Charnes, Coopeer ve Rhodes (1978) tarafindan kullanılmış (CCR Modeli), ölçeğe göre sabit getiri (Constant Return to Scale: CRS) ile analiz yapan bir tekniktir. Daha sonra ölçeğe göre değişen getiri (Variable Return to Scale: VRS) ile analiz yapan Banker, Charnes ve Cooper (1984) tarafindan kullanılan model (BCC) geliştirilmiştir. VZA, Charnes ve diğerleri (1978)'nden bu yana, üzerinde çokça çalışmalar yapılmış ve geliştirilmiş bir etkinlik ölçme yöntemidir. VZA'da ölçekler, ölçeğe göre sabit getirili (CRS) ve ölçeğe göre değişken getirili (VRS) olarak sınıflandırılmıştır. CCR modeli, CRS koşulunda bir zarflama yüzeyi oluştururken; BCC modeli VRS koşulunda bir zarflama yüzeyi oluşturmaktadır (Aybarç Bursalığlu, 2015: 218). Şekil 2'de VZA'nın modelleri özetlenmiştir.

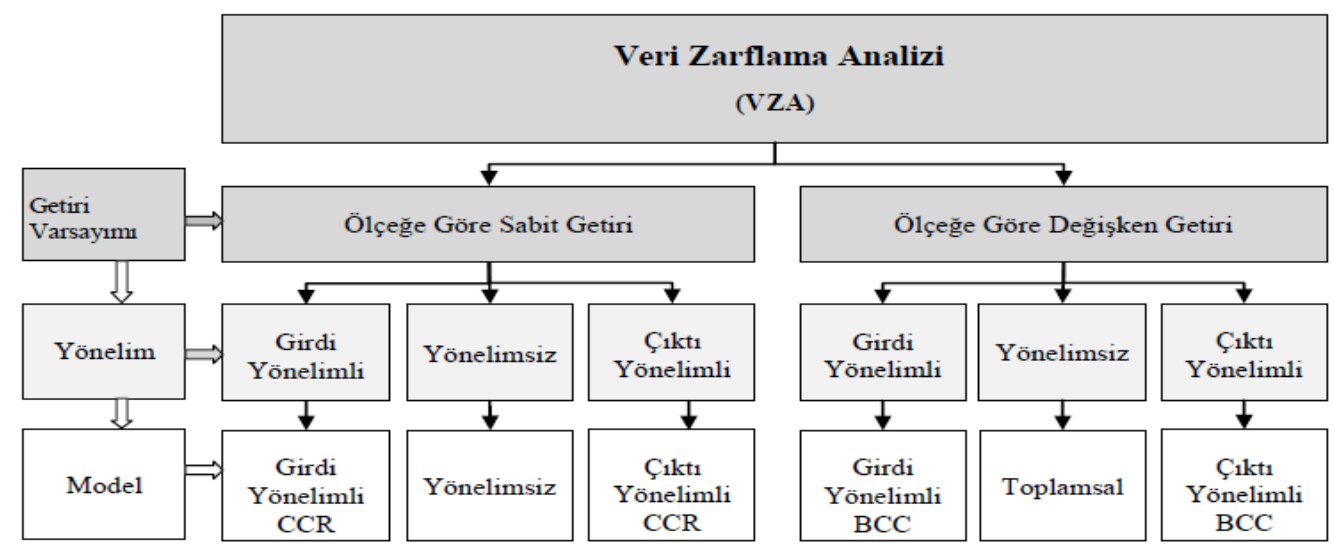

Şekil 2: Veri Zarflama Analiz Modelleri

Kaynak: Özden, 2008: s. 170.

Girdi yönelimli modellerde belirli bir çıktı bileşimini en etkin şekilde üretebilmek amacıyla kullanılacak en uygun girdi bileşiminin nasıl olması gerektiği araştırılırken çıktı yönlü modellerde belirli bir girdi bileşimi ile en fazla ne kadar çıktı bileşimi elde edilebileceği araştırılır (Charnes vd., 1981; 669; Behdioğlu ve Özcan, 2009: 305). Her bir sistemin girdi ve çıktı ağırlıklarını ve etkinlik derecelerini belirleyen farklı VZA yöntemleri vardır. Hangi 
yöntemin kullanılacă̆ı, yapılacak araştırmanın niteliğine göre değişmektedir. Karar verme birimlerinin ölçeğe göre sabit getiriye sahip oldukları varsayılıyorsa ve birimlerin toplam etkinlik skorları hesaplanmak isteniyorsa, Charnes, Cooper ve Rhodes (1978) tarafindan geliştirilen CCR modelleri kullanılabilir. Karar verme birimlerinin ölçeğe göre değişken getiriye sahip oldukları varsayıllyorsa ve yalnızca birimlerin teknik etkinlikleri hesaplanmak isteniyorsa, Banker, Charnes ve Cooper (1984) tarafindan geliştirilen BCC modelleri kullanılabilir (Uyar ve Alış, 2014). Girdi ve çıktıya yönelik CCR ve BCC modelleri aşağıda sunulmuştur.

\subsubsection{CCR Modeli}

CCR modelinin ismi, VZA'nın temellerini ilk atanlardan olan Charnes, Cooper ve Rhodes'un isimlerinin baş harflerinden gelmektedir. CCR, 1978 yıllında geliştirilmiş, matematiksel programlamaya dayalı bir modeldir. CCR modeli, $n$ KVB'nin, $m$ farklı girdi kullanarak $s$ farklı çıktı üretme sürecini ele almaktadır. CCR, VZA'nın oran yapısı, çıktıların girdilere oranıyla KVB için bağıl etkinlik ölçütü elde etmek için kullanılmaktadır. CCR modeli, çok çıktı/çok girdi durumunda, bu çok çıktı ve girdiyi sanal bir çıktı ve girdiye indirgeyerek, çarpanların fonksiyonu olan bir etkinlik ölçütü elde edilmesini sağlamaktadır (Turgutlu, 2006: 13). Tablo 1'de CCR'a yönelik girdi ve çıtı yönelimli modeller sunulmuştur.

Tablo 1'deki CCR modellerinde, $h_{k}$ : k karar biriminin etkinliği $(\mathrm{k}=1,2,3, \ldots, \mathrm{N}), m$ : girdi sayısı, $r$ : üretilen çıktı miktarı $(\mathrm{r}=1,2,3, \ldots \ldots, \mathrm{s}), i$ : kullanılan girdi miktarı $(\mathrm{i}=1,2,3, \ldots \ldots, \mathrm{m})$, $u_{r k}$ : $\mathrm{k}$ karar biriminin $\mathrm{r}$. çıktısı için belirlenen ağırlık, $y_{r k}: \mathrm{k}$ karar birimi tarafından üretilen $\mathrm{r}$ çıktı miktarı, $v_{i k}$ : k karar biriminin i. girdisi için belirlenen ağırlık, $x_{i k}$ : k karar birimi tarafindan kullanılan i girdi miktarı, $j$ : karar birimi, $n$ : karar birimi sayısı, $y_{r j}$ : j karar birimi tarafından üretilen $r$ çıktı miktarı, $x_{i j}$ : $j$ karar birimi tarafından kullanılan i girdi miktarını göstermektedir.

Tablo 1: CCR Modelleri

\begin{tabular}{|c|c|}
\hline Girdi Yönelimli CCR Modeli & Çıtı Yönelimli CCR Modeli \\
\hline $\max h_{k}=\sum_{r=1}^{s} u_{r k} y_{r k}$ & $\quad \operatorname{minh}_{k}=\sum_{i=1}^{m} v_{i k} x_{i k}$ \\
\hline$\sum_{r=1}^{s} u_{r} y_{r j}-\sum_{i=1}^{m} v_{i} x_{i j} \leq 0$ & $\sum_{i=1}^{m} v_{i} x_{i j}-\sum_{r=1}^{s} u_{r} y_{r j} \geq 0$ \\
\hline Kistlar; & Kistlar; \\
\hline$\sum_{i=1}^{m} v_{i k} x_{i k}=1$ & $\sum_{r=1}^{s} u_{r k} y_{r k}=1$ \\
\hline$u_{r} \geq 0 ; v_{i} \geq 0$ & $u_{r} \geq 0 ; v_{i} \geq 0$ \\
\hline
\end{tabular}

Kaynak: Cooper vd. (2004)'den aktaran; Aybarç Bursalığlu ve Selim, 2015: 52.

İster girdi odaklı, ister çıktı odaklı düşünülsün bir karar verici, karar noktalarının etkinliklerine CCR yöntemiyle karar vermek istiyorsa, yukarıda belirtilen modeli bütün karar noktaları için uygulamalıdır. Kurulan model, her bir karar noktası için çözüldüğünde, her bir karar noktası için TE değerleri elde edilecektir. Bu değerlerin 1'e eşit olması, karar noktaları için etkinliği, 1'den küçük olmaları ise karar noktalarının etkinsizliğini gösterir.

\subsubsection{BCC Modeli}


Literatürde çok sık kullanılmakta olan bir başka VZA modeli de Banker, Charnes, Cooper (BCC) (1984) tarafindan ortaya konulmuş̧tur. Bu modelin CCR modelinden en önemli fark1, ölçeğe göre değişen getiriye yönelik yaklaşımıdır (Turgutlu, 2006: 17). CCR modelleri, teknik etkinlikle ölçek etkinliğinin çarpımı olan teknik etkinlik skorlarını vermektedir. BCC modelleri ise ölçeğe göre değişen getiri altında etkinlik skorunu ölçmektedir ki; bu varsayım altında bulunan etkinlik skorları teknik etkinlik olarak adlandırılır. Teknik etkinlik skorunun belirlenmesiyle ölçek etkinlik skorunu da ölçmek mümkün hale gelmiştir (Kaynar, 2004: 69). BCC modelleri, girdiye yönelik ve çıktıya yönelik olarak sınıflandırılmaktadır. Tablo 2 'de girdi yönelimli ve çıktı yönelimli BCC modelleri verilmiştir.

Tablo 2'deki BCC modellerinde, $z_{k}$ ve $t_{k}$ : $\mathrm{k}$ karar biriminin etkinliği $(\mathrm{k}=1,2,3, \ldots, \mathrm{N}), i$ : kullanılan girdi miktarı $(\mathrm{i}=1,2,3, \ldots . ., \mathrm{m}), y_{r k}: \mathrm{k}$ karar birimi tarafindan üretilen $\mathrm{r}$ çıtı miktarı, $x_{i k}$ : k karar birimi tarafından kullanılan i girdi miktarı, $j$ : karar birimi, $n$ : karar birimi sayıs1, $y_{r j}$ : j karar birimi tarafından üretilen $\mathrm{r}$ çıktı miktarı, $x_{i j}$ : j karar birimi tarafından kullanılan i girdi miktarı, $k_{j k}$ ve $o_{j k}$ : konvekslik kısıtını göstermektedir. 
Tablo 2: BCC Modelleri

\begin{tabular}{|l|l|}
\hline Girdi Yönelimli BCC Modeli & Çıktı Yönelimli BCC Modeli \\
\hline $\min t_{k} ;$ & $\operatorname{maxz}_{k} ;$ \\
\hline$t_{k} x_{i k}-\sum_{j=1}^{n} o_{j k} x_{i j} \geq 0 i=1,2,3, \ldots, m$ & $z_{k} y_{r k}-\sum_{j=1}^{n} k_{j k} y_{r j} \leq 0$ \\
\hline$\sum_{j=1}^{n} o_{j k} y_{r j} \geq y_{r k} r=1,2,3, \ldots, s$ & $\sum_{j=1}^{n} k_{j k} x_{i j} \leq x_{i k}$ \\
\hline Kistlar; & Kistlar; $\quad \sum_{j=1}^{n} k_{j k}=1$ \\
\hline$\sum_{j=1}^{n} o_{j k}=1$ & $k_{j k} \geq 0$ \\
\hline$o_{j k} \geq 0$ & \\
\hline
\end{tabular}

Kaynak: Banker vd. 2004'den aktaran, Aybarç Bursalıŏlu ve Selim, 2015: 53.

\section{OECD Ülkelerinde Yükseköğretime Yönelik Etkinlik Analizi}

Her ülkenin yükseköğretim yapısı, pek çok değişkene bağlı bir şekilde oluşmaktadır. Ekonomi, bilgi toplumuna geçiş, demokrasi, artan nüfus gibi değişkenler, yükseköğretim sistemlerinin yapılanmasında rol aldığ 1 gibi ülkelerin tarihsel, coğrafik ve politik durumları da yükseköğretim yapısının şekillenmesinde etkilidir. Her ülkenin iç dinamikleri, kendine uygun yükseköğretim sistemini üretmesiyle beraber etkililik, verimlilik, başarı, katkı gibi kriterlere göre sistemlerin değerlendirilmesi de mümkündür (Güner ve Levent, 2017: 2). Bu çalışmada, 2015 yılı baz alınarak, VZA ile içerisinde Türkiye'nin de bulunduğu seçilmiş OECD ülkelerinde hem akademik performansa, hem de eğitime yönelik göstergeler kullanılarak, yükseköğretimde etkinliğin ölçülmesi amaçlanmıştır. Uygulanan VZA adımları aşağıda sunulmuşstur.

\subsection{Karar Verme Birimlerinin Seçimi}

$\mathrm{Bu}$ aşama, VZA sonuçlarının geçerliliği açısından çok önemlidir. VZA, karşılaştırmalı bir analiz olduğu için doğru karar birimlerinin analize alınması gerekmektedir. Bu çalışmada ele alınan KVB'leri, seçilmiş OECD üyesi ülkelerini kapsamaktadır. Bu çalışmada ele alınan girdi ve çıktı değişkenleri için tüm OECD ülkelerine ait veri bulunamadığından gözlem kümesi içerisinde yer alan akademik performansa yönelik değişken seti ile 25 OECD ülkesi ve eğitime yönelik iki farklı değişken seti ile sırasıyla 24 ve 25 OECD ülkesi, benzer girdi ve çıktıyı üreten KVB olarak belirlenmiştir. Analiz için ele alınan seçilmiş OECD ülkeleri, yani KVB'leri Tablo 3, Tablo 4 ve Tablo 5'in ilk sütununda gösterilmiştir.

\subsection{Girdi ve Çıktı Parametrelerinin Belirlenmesi}

Seçilecek olan girdi ve çıktı kümesi tüm karar noktaları için ortak faktörler olarak alınmış ve buna göre girdi ve çıktı değişkenleri belirlenmiştir. Seçilmiş KVB'leri için değişkenlere ait veriler 2018 y1l "Education at a Glance" ve OECD istatistiklerinden elde edilmiştir. OECD 2018 y1lı raporunda, tüm değişkenlere ilişkin en güncel veriler 2015 y1lına ait olduğu için çalışmada baz yıl olarak 2015 yılı alınmıştır.

Girdi ve çıktı değişkenlerin belirlenmesine yönelik yararlanılan literatürde yapılmış çalışmalardan Wolszczak Derlacz (2017), yayın sayısı, akademik personel sayısı ve toplam öğrenci sayısı değişkenlerini kullanmıştır. Agasisti (2009), yükseköğretim kamu harcamalarına analizlerinde yer vermiştir. Toth (2009), VZA ile aralarında Türkiye'nin de 
yer aldığ toplam 19 Avrupa ülkesini incelemiș ve yükseköğretim hizmetine aktarılan kamu kaynaklarını, ele aldığı modellerde kullanmıştır. Aybarç Bursalığlu (2013), yükseköğretim kamu harcamalarının Gayrisafi Milli Hasıla'ya oranı, akademisyen başına düşen öğrenci sayıs1, akademisyen sayısı, yükseköğretim mezunlarının istihdam oranı, yükseköğretim mezunlarının toplam nüfusa oranı ve yükseköğretimli bireylerin yaşam memnuniyeti değişkenlerine analizlerinde yer vermiştir.

Bu çalışmada ise akademik performansa yönelik etkinlik analizlerinde 3 girdi ve 2 çıktı değişken kullanılmıştır. Her iki eğitime yönelik etkinlik analizinde ise 4 girdi ve 2 çıktı değişken kullanılmıştır. Girdi ve çıktı değişkeni sayısına uygun olarak KVB seçimi yapılmıştır. Yükseköğretim kurumları, sadece mezun veren değil, aynı zamanda işgücü piyasası için eğitimli işgücü potansiyeli arz eden birimlerdir. Bu nedenle eğitime yönelik analizlerde, çıktı değişkenleri arasında belki de en önemli gösterge olan yükseköğretim mezunlarının istihdam oranları alınmıștır. Diğer çıktı değişkenler ise yaşam memnuniyeti ile yükseköğretim mezunlarının elde ettikleri ortalama kazançtır. $\mathrm{Bu}$ çıktıların tümü yükseköğretim kurumlarının kalite göstergeleri arasındadır. Eğitime yönelik yapılan analizlerin ilkinde girdi değişkenleri olarak tam zamanlı eşdeğer öğrenci başına düşen yükseköğretim kurumlarına yönelik toplam harcamalar, yükseköğretim kurumlarına yönelik toplam kamu harcamalarının GSYİH içindeki payı, yükseköğretim kurumlarına yönelik toplam özel sektör harcamalarının GSYİH içindeki payı ve akademisyen sayısı, ikincisinde ise tam zamanlı eşdeğer öğrenci başına düşen yükseköğretim kurumlarına yönelik toplam harcamalar, yükseköğretim kurumlarına yönelik toplam kamu harcamalarının GSYİH içindeki payı, yükseköğretim kurumlarına yönelik toplam özel sektör harcamalarının GSYİH içindeki payı ve yükseköğretime erişim oranı kullanılmıştır. Yükseköğretimin kalite göstergelerinden biri de akademik performansa yönelik yapılan çalışmalardır. Akademik performansa dayalı etkinlik analizlerinde ise bilimsel verimliliği gösteren yayın sayıları ve atıf sayıları çıktı değişken olarak alınmıştır. Girdi değişkenleri ise kamu ve özel yükseköğretim kurumlarında AR-GE'ye yönelik toplam harcamalar, akademisyen sayısı ve akademisyen başına düşen öğrenci sayısıdır.

\subsection{Uygun VZA Modelinin Belirlenmesi}

$\mathrm{Bu}$ çalışmada asıl amaç, mevcut girdiler ile maksimum çıktının sağlanması olduğu için çıktı odaklı ve VRS tipi şeklinde zarflama yüzeyi seçilerek analiz yapılmıştır. Tibenszkyne (2007), çıktı odaklı yaklaşımın yükseköğretim açısından daha uygun olduğunu ve eğitim sürecinde kaynak uyumunun daima aynı olmayacağını da göz önünde bulundurarak, VRS tipi zarflama yüzeyinin seçilmesinin daha uygun olacağını vurgulamıştır (Aybarç Bursalığlu, 2013). Bu çalışmada etkinlik değerlerinin elde edilmesinde FRONTIER ANALYST paket programından faydalanılmıştır.

\subsubsection{Akademik Performansa Yönelik Etkinlik Analizi}

Tablo 3'te, seçilmiş OECD ülkelerine ait akademik performansa yönelik etkinlik skorları, referans alınan ülkeler ve potansiyel iyileştirme oranları sunulmuştur. Şekil 3'te ise, etkinlik değerlerinin dağılımı görülmektedir. 


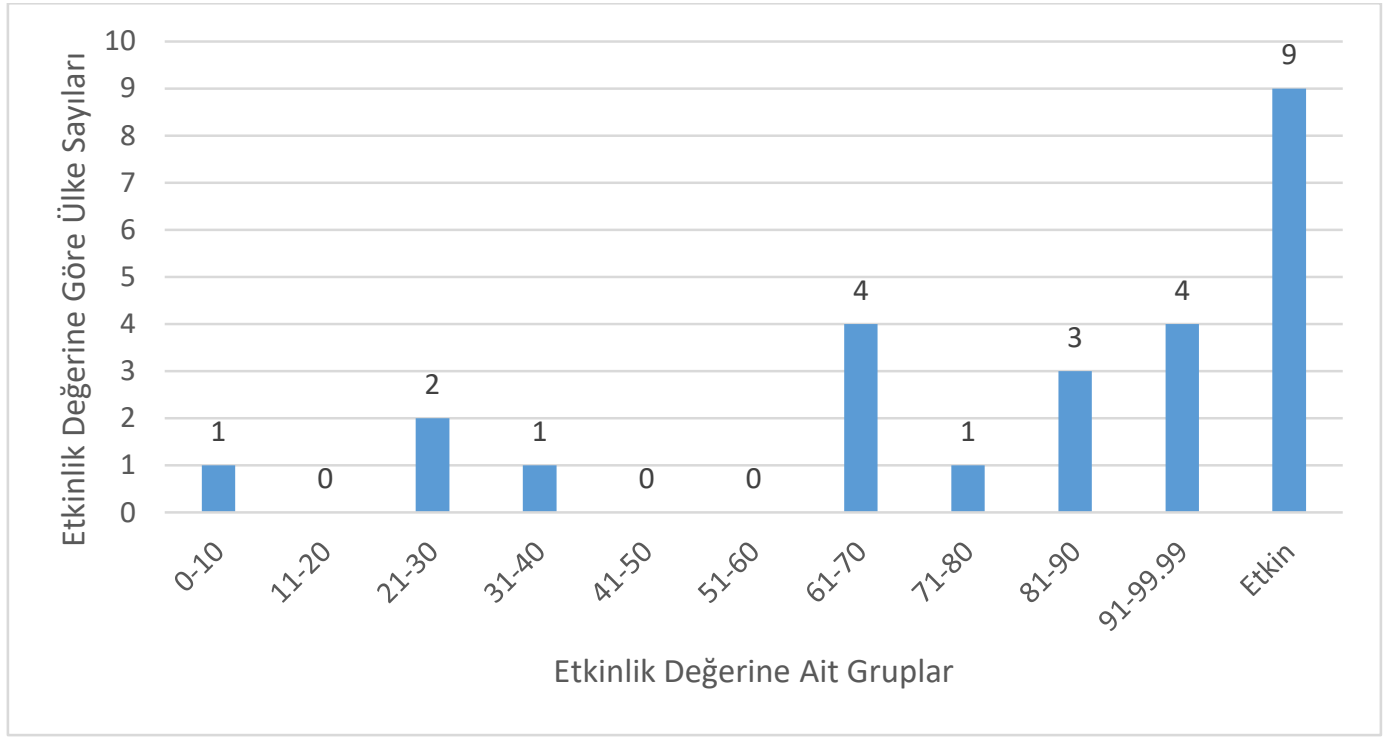

Şekil 3: Akademik Performansa Yönelik Etkinlik Değerlerin Dağılımı

Akademik performansa göre etkin olan 9 ülke bulunmaktadır. 25 ülke içerisinde etkin olan 9 ülke, Estonya, Finlandiya, İrlanda, Letonya, Lüksemburg, Slovenya, İsveç, Birleşik Krallık ve ABD'dir. 100'ün altında olan etkinlik değerleri, o ülkelerin etkin olmadığını göstermektedir. Türkiye, Meksika'dan sonra ikinci en düşük etkinlik değerine sahip ülke olmuştur. Türkiye'yi Polonya ve Macaristan izlemektedir. Bilim ve teknoloji üreten ülkelerin başarısı da eğitim ve bilime, yaratıcı teknolojiye verdikleri önem ve bu iş için harcanan bütçeye dayanmaktadır. Türkiye, son 15 yılda GSMH'sının \%1'inin altında araştırmaya pay ayırmıştır. Doğal olarak bilimsel araştırmaya ayrılan bütçe ile bilimsel yayın sayıları ve kalitesi arasında da göreceli bir ilişki bulunmaktadır (Ortaş, 2018). Buna dayanarak analiz sonucunda, Türkiye'nin son sıralarda yer almasının doğal bir sonuç olduğu söylenebilir.

Etkin olmayan ülkelerin etkin sınıra ulaşabilmeleri için gerekli potansiyel iyileştirme oranları, "gerçekleşen veriler" ile "hedeflenen veriler" arasındaki orana göre tespit edilmektedir. Etkin olmayan ülkelerin etkin sınıra ulaşabilmesi, yani potansiyel iyileştirme oranlarının elde edilmesi ile çıktı değişkeninin yüzde kaç arttırılması veya azaltılması gerektiği ortaya çıkmaktadır. Potansiyel iyileştirme oranları incelendiğinde etkin sınırda yer almayan Avusturya'nın referans alınan Lüksemburg, Slovenya, Birleşik Krallık'a göre etkin olabilmesi için girdileri sabit tutulduğunda, yayın sayısını $\% 67.7$ ve atıf sayısını da $\% 53.5$ oranında arttırması gerekmektedir. Bunun yanında en düşük etkinlik skoruna sahip olan Meksika'nın etkin olan Lüksemburg, Birleşik Krallık, ABD referans alındığında, etkin olabilmesi için yayın sayısını \%1270.2 ve atıf sayısını da \%1774.8 oranında arttırması gerekmektedir. Türkiye'ye bakıldığında ise referans ülkeleri olan Birleşik Krallık ve ABD'ye göre etkin olabilmesi için yayın ve atıf sayılarını sırasıyla \%380.2 ve \%795.4 oranında arttırmalidir. 
Tablo 3: Akademik Performansa Yönelik Etkinlik Değerleri, Referans Alınan Ülkeler ve Potansiyel İyileștirme Oranları

\begin{tabular}{|c|c|c|c|c|c|c|c|c|}
\hline \multirow[b]{2}{*}{ Ülkeler } & \multirow[b]{2}{*}{$\begin{array}{l}\text { Etkinlik } \\
\text { Değerleri } \\
\end{array}$} & \multirow[b]{2}{*}{ Referans Ülkeler } & \multicolumn{2}{|c|}{ Gerçek Değerler } & \multicolumn{2}{|c|}{ Hedeflenen Değerler } & \multicolumn{2}{|c|}{$\begin{array}{c}\text { Potansiyel İyileştirme } \\
\text { Oranları (\%) }\end{array}$} \\
\hline & & & Yayın sayısı & Atıf sayısı & $\begin{array}{l}\text { Yayın } \\
\text { sayısı }\end{array}$ & Atıf sayısı & $\begin{array}{l}\text { Yayın } \\
\text { sayısı }\end{array}$ & Atıf sayısı \\
\hline Avusturya & 65.16 & Lüksemburg, Slovenya, Birleşik Krallık & 24239 & 237173 & 40645.92 & 364005.2 & 67.7 & 53.5 \\
\hline Belçika & 97.04 & Finlandiya, İrlanda, Birleşik Krallık & 33494 & 358471 & 38679.05 & 369408.1 & 15.5 & 3.1 \\
\hline Çek Cumhuriyeti & 95.33 & İrlanda, Birleşik Krallık & 23451 & 143995 & 24599.48 & 219777.7 & 4.9 & 52.6 \\
\hline Estonya & 100 & - & 2792 & 38366 & 2792 & 38366 & 0 & 0 \\
\hline Finlandiya & 100 & - & 18816 & 202169 & 18816 & 202169 & 0 & 0 \\
\hline Fransa & 78.09 & Finlandiya, Birleşik Krallık & 112214 & 1056158 & 149192.2 & 1352532 & 33 & 28.1 \\
\hline Almanya & 84.77 & Lüksemburg, Birleşik Krallık, ABD & 163503 & 1593463 & 217699.3 & 1879774 & 33.1 & 18 \\
\hline Macaristan & 38.05 & Finlandiya, İsveç, Birleşik Krallık & 10387 & 84840 & 27298.45 & 277502.7 & 162.8 & 227.1 \\
\hline İrlanda & 100 & - & 14742 & 130961 & 14742 & 130961 & 0 & 0 \\
\hline İtalya & 86.09 & İrlanda, Birleşik Krallık & 106941 & 959184 & 124222 & 1117386 & 16.2 & 16.5 \\
\hline Letonya & 100 & - & 1938 & 7763 & 1938 & 7763 & 0 & 0 \\
\hline Lüksemburg & 100 & - & 1794 & 18415 & 1794 & 18415 & 0 & 0 \\
\hline Meksika & 7.3 & Lüksemburg, Birleşik Krallık, ABD & 19195 & 123114 & 263013.6 & 2308153 & 1270.2 & 1774.8 \\
\hline Hollanda & 88.12 & Finlandiya, Lüksemburg, İsveç, Birleşik Krallık & 59246 & 685842 & 84131.16 & 778345.8 & 42 & 13.5 \\
\hline Yeni Zelanda & 64.84 & Estonya, Finlandiya, İrlanda, Birleşik Krallık & 13859 & 129682 & 21507 & 200008.7 & 55.2 & 54.2 \\
\hline Norveç & 67.52 & Finlandiya, Lüksemburg, İsveç, Birleşik Krallık & 18832 & 194511 & 27889.67 & 297379.1 & 48.1 & 52.9 \\
\hline Polonya & 29.75 & Estonya, Finlandiya, Lüksemburg, Birleşik Krallık & 39161 & 255228 & 131642.4 & 1192424 & 236.2 & 367.2 \\
\hline Portekiz & 96.45 & Lüksemburg, Slovenya, Birleşik Krallık & 23096 & 182141 & 23946.89 & 213340.4 & 3.7 & 17.1 \\
\hline Slovakya & 64.11 & Estonya, Finlandiya, Lüksemburg, Birleşik Krallık & 7441 & 39687 & 11607.21 & 115297.3 & 56 & 190.5 \\
\hline
\end{tabular}




\begin{tabular}{|c|c|c|c|c|c|c|c|c|}
\hline \multirow[b]{2}{*}{ Ülkeler } & \multirow[b]{2}{*}{$\begin{array}{l}\text { Etkinlik } \\
\text { Değerleri }\end{array}$} & \multirow[b]{2}{*}{ Referans Ülkeler } & \multicolumn{2}{|c|}{ Gerçek Değerler } & \multicolumn{2}{|c|}{ Hedeflenen Değerler } & \multicolumn{2}{|c|}{$\begin{array}{c}\text { Potansiyel İyileştirme } \\
\text { Oranları (\%) }\end{array}$} \\
\hline & & & Yayın sayısı & Atıf sayısı & $\begin{array}{l}\text { Yayın } \\
\text { sayısı }\end{array}$ & Atıf sayısı & $\begin{array}{l}\text { Yayın } \\
\text { Sayısı }\end{array}$ & Atıf sayısı \\
\hline Slovenya & 100 & - & 5466 & 44126 & 5466 & 44126 & 0 & 0 \\
\hline İspanya & 92.53 & Lüksemburg, Slovenya, Birleşik Krallık & 86595 & 769187 & 93587.73 & 842490.1 & 8.1 & 9.5 \\
\hline İsveç & 100 & - & 38612 & 431309 & 38612 & 431309 & 0 & 0 \\
\hline Türkiye & 20.83 & Birleşik Krallık, ABD & 42434 & 204825 & 203759 & 1833921 & 380.2 & 795.4 \\
\hline Birleşik Krallık & 100 & - & 203631 & 1832868 & 203631 & 1832868 & 0 & 0 \\
\hline ABD & 100 & - & 687697 & 5814614 & 687697 & 5814614 & 0 & 0 \\
\hline
\end{tabular}




\subsubsection{Eğitime Yönelik Etkinlik Analizi}

Eğitime yönelik etkinliğin elde edilmesinde iki farklı analiz (Eğitim 1 ve Eğitim 2) gerçekleştirilmiştir. Bunun nedeni, VZA kapsamında KVB, kullanılan girdi ve çıktı değişkenlerin sayısı ve elde edilen sonuçların tutarlılı̆̆ının gözetilmesidir.

Şekil 4'te, Eğitim 1'e yönelik gerçekleştirilen analizlerden elde edilen etkinlik değerlerinin dağılımı görülmektedir. Eğitim 1'e göre etkin olan 15 ülke bulunmaktadır. 24 ülke içerisinde etkin olan 15 ülke, Çek Cumhuriyeti, Finlandiya, Macaristan, İrlanda, İtalya, Japonya, Letonya, Lüksemburg, Yeni Zelanda, Norveç, Polonya, Portekiz, Slovakya, Slovenya ve İsveç'tir (bkz. Tablo 4). Tablo 4 incelendiğinde en düşük etkinlik değerine sahip ülkenin Kore olduğu görülmektedir. Bunu, \% 93.81 etkinlik değeri ile Türkiye ve ABD izlemektedir. TÜİK (2016) İşgücü Araştırması sonuçlarına göre, Türkiye'de yükseköğretim mezunu olanların \%70,1'i istihdamda, \%9,6'sı işsiz, \%20,3'ü ise işgücü dışında yer almıştır. Analizden elde edilen bu sonucun nedeni olarak işsizliğin, açılan yükseköğretim kurumlarının istihdam ile örtüşmeyecek derecede fazla mezun vermesinden kaynaklandığ söylenebilir.

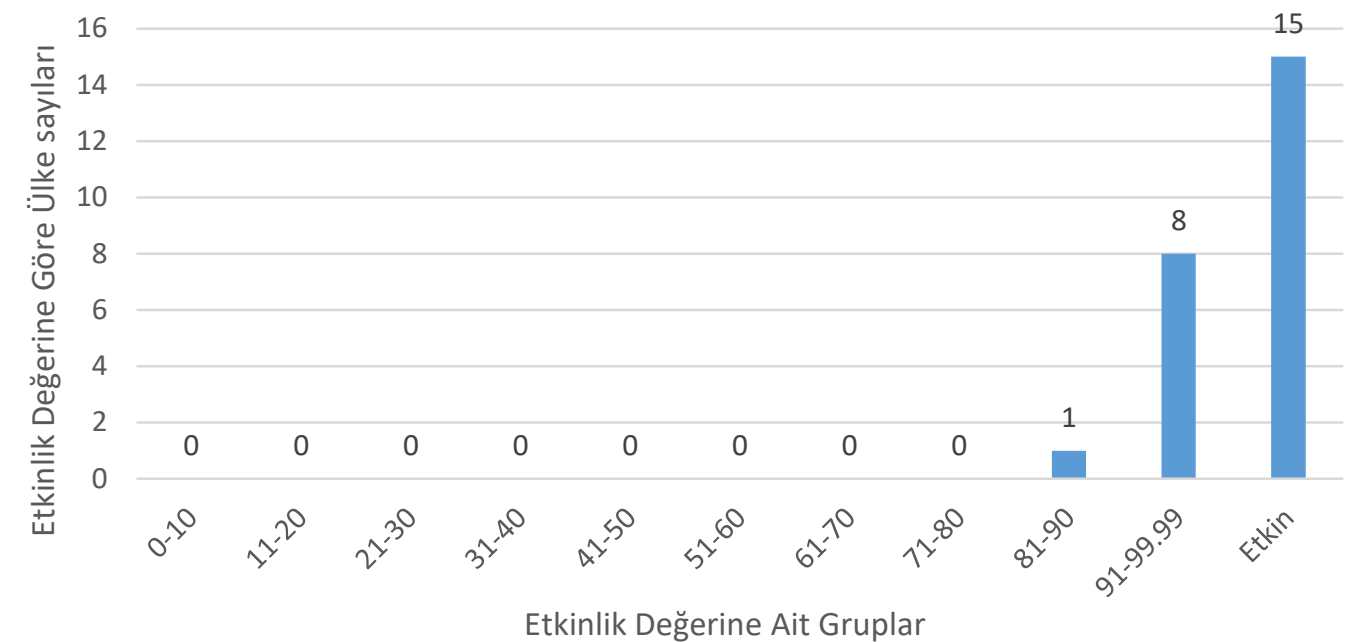

Şekil 4: Eğitim 1'e Yönelik Etkinlik Değerlerin Dağılımı

Tablo 4'teki potansiyel iyileştirme oranları incelendiğinde, etkin sınırda yer almayan Kore'nin referans alınan ülkeler olan Macaristan, Polonya, Portekiz'e göre etkin sinıra ulaşabilmesi için yükseköğretim mezunlarının istihdam oranlarını $\% 11.9$ ve yaşam memnuniyetlerini \%15.2 arttırması gerekmektedir. Hollanda'nın ise etkin olabilmesi için referans ülkeleri olan İsveç, Norveç, Yeni Zelanda ile karşılaştırıldığında, sadece yükseköğretim mezunlarının yaşam memnuniyetini \%1.4 oranında arttırması yeterli olacaktır. Türkiye'ye bakıldığında, etkin olabilmesi için etkin olan Macaristan, Polonya referans alındığında, yükseköğretim mezunlarının istihdam oranını $\% 13.9$ ve yaşam memnuniyetini $\% 6.6$ oranında arttırmalıdır. 
Tablo 4: Eğitim 1'e Yönelik Etkinlik Değerleri, Referans Alınan Ülkeler ve Potansiyel İyileștirme Oranları

\begin{tabular}{|c|c|c|c|c|c|c|c|c|}
\hline \multirow[b]{2}{*}{ Ülkeler } & \multirow[b]{2}{*}{$\begin{array}{l}\text { Etkinlik } \\
\text { Değerleri }\end{array}$} & \multirow[b]{2}{*}{ Referans Ülkeler } & \multicolumn{2}{|c|}{ Gerçek Değerler } & \multicolumn{2}{|c|}{ Hedeflenen Değerler } & \multicolumn{2}{|c|}{$\begin{array}{c}\text { Potansiyel İyileştirme } \\
\text { Oranları (\%) } \\
\end{array}$} \\
\hline & & & $\begin{array}{c}\text { İstihdam } \\
\text { oranı }\end{array}$ & $\begin{array}{c}\text { Yaşam } \\
\text { memnuniyeti }\end{array}$ & $\begin{array}{c}\text { İstihdam } \\
\text { oranı }\end{array}$ & $\begin{array}{c}\text { Yaşam } \\
\text { memnuniyeti }\end{array}$ & $\begin{array}{c}\text { İstihdam } \\
\text { oranı }\end{array}$ & $\begin{array}{c}\text { Yaşam } \\
\text { memnuniyeti }\end{array}$ \\
\hline Avusturya & 97.06 & Norveç, Polonya, Slovenya & 86 & 84 & 88.62 & 94.72 & 3 & 12.7 \\
\hline Belçika & 97.87 & $\begin{array}{l}\text { Çek Cumhuriyeti, Norveç, } \\
\text { Slovakya, İsveç }\end{array}$ & 85 & 95 & 86.85 & 97.07 & 2.2 & 2.2 \\
\hline Çek Cumhuriyeti & 100 & - & 86 & 96 & 86 & 96 & 0 & 0 \\
\hline Finlandiya & 100 & - & 85 & 95 & 85 & 95 & 0 & 0 \\
\hline Fransa & 96.7 & $\begin{array}{l}\text { Çek Cumhuriyeti, Letonya, } \\
\text { Yeni Zelanda, Polonya, İsveç }\end{array}$ & 85 & 93 & 87.9 & 96.18 & 3.4 & 3.4 \\
\hline Macaristan & 100 & - & 85 & 83 & 85 & 83 & 0 & 0 \\
\hline İrlanda & 100 & - & 85 & 93 & 85 & 93 & 0 & 0 \\
\hline İtalya & 100 & - & 81 & 89 & 81 & 89 & 0 & 0 \\
\hline Japonya & 100 & - & 84 & 85 & 84 & 85 & 0 & 0 \\
\hline Kore & 89.35 & Macaristan, Polonya, Portekiz & 77 & 75 & 86.18 & 86.41 & 11.9 & 15.2 \\
\hline Letonya & 100 & - & 88 & 94 & 88 & 94 & 0 & 0 \\
\hline Lüksemburg & 100 & - & 86 & 95 & 86 & 95 & 0 & 0 \\
\hline Hollanda & 99.9 & İsveç, Norveç, Yeni Zelanda & 89 & 96 & 89 & 97.37 & 0 & 1.4 \\
\hline Yeni Zelanda & 100 & - & 89 & 97 & 89 & 97 & 0 & 0 \\
\hline Norveç & 100 & - & 89 & 97 & 89 & 97 & 0 & 0 \\
\hline Polonya & 100 & - & 88 & 91 & 88 & 91 & 0 & 0 \\
\hline Portekiz & 100 & - & 87 & 89 & 87 & 89 & 0 & 0 \\
\hline
\end{tabular}




\begin{tabular}{|l|l|l|c|c|c|c|c|c|}
\hline Slovakya & 100 & - & 82 & 98 & 82 & 98 & 0 \\
\hline Slovenya & 100 & - & 87 & 85 & 87 & 85 & 0 \\
\hline İspanya & 97.85 & $\begin{array}{l}\text { Çek Cumhuriyeti, Lüksemburg, } \\
\text { Yeni Zelanda }\end{array}$ & 81 & 94 & 86.3 & 96.07 & 0 \\
\hline İsvec & 100 & - & 89 & 98 & 89 & 98 & 0 \\
\hline Türkiye & 93.81 & Macaristan, Polonya & 75 & 79 & 85.45 & 84.21 & 13.9 & 6.6 \\
\hline Birleşik Krallık & 99.65 & Japonya, Lüksemburg, Portekiz & 85 & 87 & 85.3 & 88.91 & 0.35 \\
\hline ABD & 93.81 & Yeni Zelanda & 82 & 91 & 89 & 97 & 2.2 \\
\hline
\end{tabular}


Şekil 5, Eğitim 2'ye yönelik analizlerden elde edilen etkinlik değerlerinin dağılımını göstermektedir. Buna göre etkin olan 13 ülke bulunmaktadır. 25 ülke içerisinde etkin olan 13 ülke, Avusturya, Şili, Çek Cumhuriyeti, Finlandiya, Almanya, Yunanistan, İrlanda, İtalya, Japonya, Litvanya, Norveç, Slovenya ve Birleşik Krallık’tır. En düşük etkinlik değerine sahip ülke, Türkiye'dir. Bu sırayı İspanya, $\mathrm{ABD}$ ve Belçika izlemektedir (bkz. Tablo 5). Türkiye'nin en son sırada olmasının nedenleri arasında, kamu harcamalarının eğitime ayrılan payının düşüklüğü, istihdam imkânı olan alanların azlığı gösterilmektedir. Tablo 5 'teki potansiyel iyileştirme oranları incelendiğinde, etkin sınırda yer almayan Kore'nin referans alınan ülkeler olan Yunanistan, İtalya, Litvanya'ya göre, yükseköğretim mezunlarının istihdam oranını \%5.3 oranında ve ortalama kazançlarını da \%3.8 oranında arttırması gerekmektedir. Türkiye'ye bakıldığında, referans ülkeler olan Yunanistan ve Litvanya'ya göre, yükseköğretim mezunlarının istihdam oranını \%17.9 ve ortalama kazançları da \%150.3 oranında arttırması gerekir. Yükseköğretim mezunlarının ortalama kazancını en fazla oranda arttırması gereken ülkeler, Estonya, Türkiye ve Slovakya'dır. Gözlem kümesi içerisinde yükseköğretim mezunlarının istihdam oranlarını en fazla arttırması gereken ülke ise Türkiye'dir.

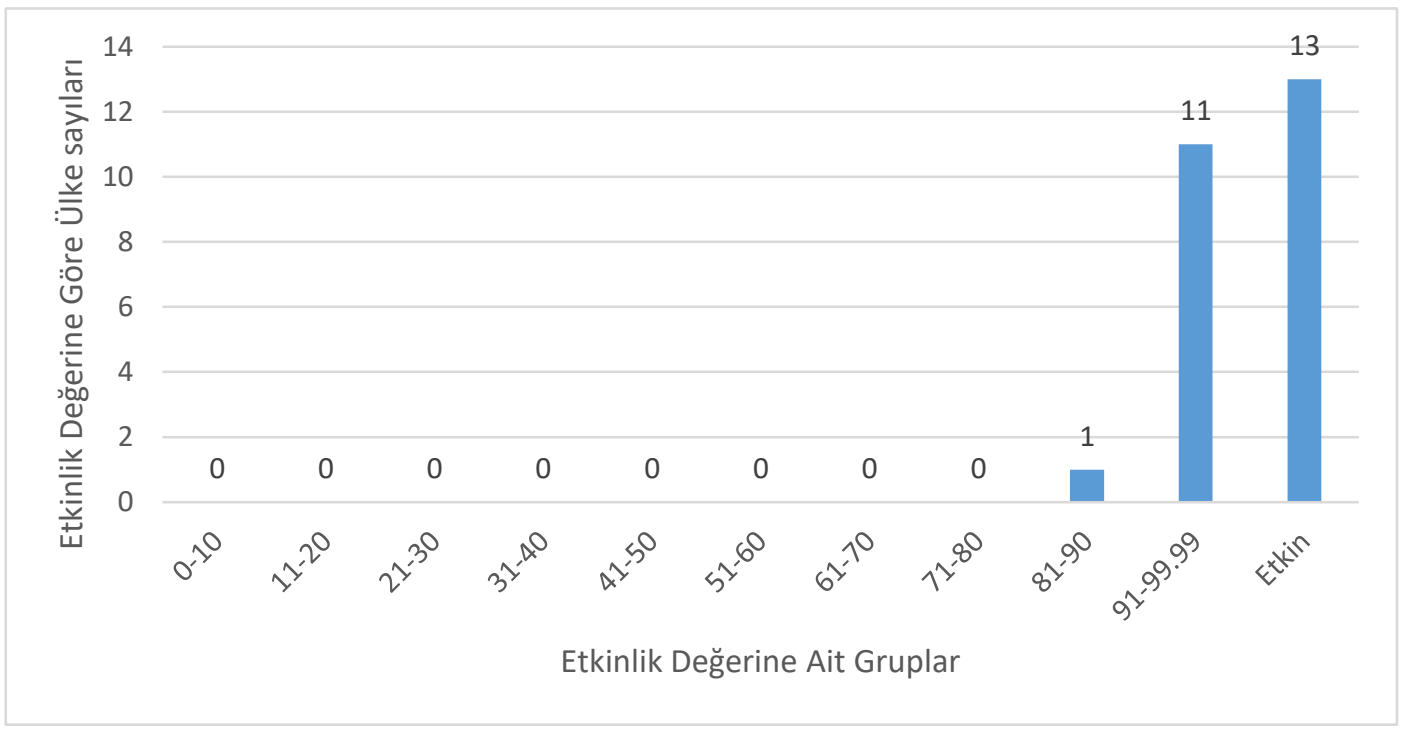

Şekil 5: Eğitim 2'ye Yönelik Etkinlik Değerlerin Dağılımı 
Tablo 5: Eğitim 2'ye Yönelik Etkinlik Değerleri, Referans Alınan Ülkeler ve Potansiyel İyileștirme Oranları

\begin{tabular}{|c|c|c|c|c|c|c|c|c|}
\hline \multirow[b]{2}{*}{ Ülkeler } & \multirow[b]{2}{*}{$\begin{array}{l}\text { Etkinlik } \\
\text { Değerleri }\end{array}$} & \multirow[b]{2}{*}{ Referans Ülkeler } & \multicolumn{2}{|c|}{ Gerçek Değerler } & \multicolumn{2}{|c|}{ Hedeflenen Değerler } & \multicolumn{2}{|c|}{$\begin{array}{c}\text { Potansiyel İyileștirme } \\
\text { Oranları (\%) } \\
\end{array}$} \\
\hline & & & $\begin{array}{c}\text { İstihdam } \\
\text { oranı }\end{array}$ & $\begin{array}{l}\text { Ortalama } \\
\text { kazanç }\end{array}$ & $\begin{array}{c}\text { İstihdam } \\
\text { oranı }\end{array}$ & $\begin{array}{l}\text { Ortalama } \\
\text { kazanç }\end{array}$ & $\begin{array}{c}\text { İstihdam } \\
\text { oranı }\end{array}$ & $\begin{array}{c}\text { Ortalama } \\
\text { kazanç }\end{array}$ \\
\hline Avustralya & 95.49 & Litvanya, Birleşik Krallık & 84 & 3766.67 & 87.97 & 5387.15 & 4.7 & 43 \\
\hline Avusturya & 100 & - & 86 & 4375 & 86 & 4375 & 0 & 0 \\
\hline Belçika & 94.87 & Almanya, Litvanya, Norveç & 85 & 4025 & 89.59 & 4313.61 & 5.4 & 7.2 \\
\hline Şili & 100 & - & 84 & 2200 & 84 & 2200 & 0 & 0 \\
\hline Çek Cumhuriyeti & 100 & - & 86 & 1950 & 86 & 1950 & 0 & 0 \\
\hline Estonya & 96.2 & $\begin{array}{l}\text { Çek Cumhuriyeti, Almanya, } \\
\text { Litvanya }\end{array}$ & 86 & 1533.33 & 89.4 & 4142.89 & 4 & 170.2 \\
\hline Finlandiya & 100 & - & 85 & 3250 & 85 & 3250 & 0 & 0 \\
\hline Fransa & 96.79 & Çek Cumhuriyeti, Almanya, İtalya & 85 & 2916.67 & 87.82 & 3861.48 & 3.3 & 32.4 \\
\hline Almanya & 100 & - & 89 & 4016.67 & 89 & 4016.67 & 0 & 0 \\
\hline Yunanistan & 100 & - & 72 & 1966.67 & 72 & 1966.67 & 0 & 0 \\
\hline İrlanda & 100 & - & 85 & 3600 & 85 & 3600 & 0 & 0 \\
\hline İsrail & 98.89 & Çek Cumhuriyeti, İrlanda, Litvanya & 87 & 2683.33 & 87.98 & 3828.58 & 1.1 & 42.7 \\
\hline İtalya & 100 & - & 81 & 3075 & 81 & 3075 & 0 & 0 \\
\hline Japonya & 100 & - & 84 & 3033.33 & 84 & 3033.33 & 0 & 0 \\
\hline Kore & 96.3 & Yunanistan, İtalya, Litvanya & 77 & 3066.67 & 81.11 & 3184.48 & 5.3 & 3.8 \\
\hline Litvanya & 100 & - & 91 & 5050 & 91 & 5050 & 0 & 0 \\
\hline Hollanda & 97.8 & Litvanya & 89 & 4400 & 91 & 5050 & 2.25 & 14.8 \\
\hline
\end{tabular}




\begin{tabular}{|c|c|c|c|c|c|c|c|c|}
\hline Norveç & 100 & - & 89 & 3983.33 & 89 & 3983.33 & 0 & 0 \\
\hline Slovakya & 95.47 & Almanya, İtalya, Japonya & 82 & 1850 & 85.89 & 3608.71 & 4.7 & 95.1 \\
\hline Slovenya & 100 & - & 87 & 2533.33 & 87 & 2533.33 & 0 & 0 \\
\hline İspanya & 92.04 & $\begin{array}{l}\text { Çek Cumhuriyeti, Almanya, İrlanda, } \\
\text { Japonya, Litvanya }\end{array}$ & 81 & 2733.33 & 88 & 3881.05 & 8.6 & 42 \\
\hline İsveç & 99.59 & Almanya, Litvanya, Norveç & 89 & 3216.67 & 89.37 & 4195.17 & 0.4 & 30.4 \\
\hline Türkiye & 84.82 & Yunanistan, Litvanya & 75 & 1850 & 88.42 & 4630.91 & 17.9 & 150.3 \\
\hline Birleşik Krallık & 100 & - & 85 & 5716.67 & 85 & 5716.67 & 0 & 0 \\
\hline ABD & 93.18 & Litvanya, Birleşik Krallık & 82 & 5016.67 & 88 & 5383.6 & 7.3 & 7.3 \\
\hline
\end{tabular}




\section{Sonuç}

Günümüzde yükseköğretimin önemi, bilgi üreten ana kurumlar olması nedeniyle artmıştır. Alan çeşitliliği sayesinde yükseköğretim, her türlü bilginin doğum noktası olmuştur. İlköğretim mezunu ile yükseköğretim mezunu bireylerin ekonomik koşulları arasında belirgin farklı1ıklar gözlenmesi, yükseköğretime yönelik talebin nedenleri arasındadır. Talebi karşılamaya yönelik bir takım düzenlemeler, devlet tarafından önceleri gerçekleştirilmiş, ancak kamu kuruluşları talebi karşılamada yetersiz kalınca, özel kuruluşlar ile yeni girişimler yapılmıştır. Ancak talep karşılansa da yükseköğretim kurumlarının ne derece etkin çalıştı̆̆ının ve yeterliliğinin denetlenmesi gerekmektedir. Yükseköğretim hizmetinde maliyet minimizasyonu ilkesinin uygulanamaması, analiz yaklaşımı olarak çıktı odaklılı̆̆ın seçimini güçlü kılmaktadır. Bu nedenle, bu çalışma kapsamında yükseköğretim kamu harcamalarının etkinlik analizini gerçekleştirmek için mevcut girdiler ile maksimum çıtıyı elde eden "çıktı odaklı"; yani BCC Modeli kullanılmıştır. Zarflama yüzeyi seçiminde ise karar birimleri arasındaki ölçek farklılıklarını dikkate alarak, etkinlik skorlarını belirleyen ve bu noktada CRS yüzey tipine göre üstünlük sağlayan VRS yüzey tipi seçilmiştir.

$\mathrm{Bu}$ çalışmada, akademik performansa yönelik etkinlik analiz sonucunda, 9 ülke tam etkin olarak bulunmuştur. Bu ülkeler, Estonya, Finlandiya, İrlanda, Letonya, Lüksemburg, Slovenya, İsveç, Birleşik Krallık ve ABD'dir. Türkiye, Meksika'dan sonra ikinci en düşük etkinliğe sahip ülkedir. Potansiyel iyileştirme oranları hesaplandığında, Türkiye'nin etkin olabilmesi için yayın ve atıf sayılarını sırasıyla \%380.2 ve \%795.4 oranında arttırması gerektiği görülmektedir. Eğitime yönelik etkinliğin elde edilmesinde, ilk analiz sonucunda etkin bulunan OECD ülkeleri Çek Cumhuriyeti, Finlandiya, Macaristan, İrlanda, İtalya, Japonya, Letonya, Lüksemburg, Yeni Zelanda, Norveç, Polonya, Portekiz, Slovakya, Slovenya ve İsveç'tir. Türkiye'ye bakıldığında, etkin olabilmesi için referans alınan Macaristan, Polonya ile karşılaştırıldığında, yükseköğretim mezunlarının istihdam oranını $\% 13.9$ ve yaşam memnuniyetini \%6.6 oranında arttırmalıdır. İkinci analiz sonucunda etkin olan 13 ülke, Avusturya, Şili, Çek Cumhuriyeti, Finlandiya, Almanya, Yunanistan, İrlanda, İtalya, Japonya, Litvanya, Norveç, Slovenya ve Birleşik Krallık'tır. Bu analizde en düşük etkinlik değerine sahip ülke, Türkiye'dir. Bu sırayı İspanya, ABD ve Belçika izlemiştir. Türkiye'ye bakıldığında referans ülkeler olan Yunanistan ve Litvanya'ya göre, yükseköğretim mezunlarının istihdam oranını \%17.9 ve ortalama kazançları da \%150.3 oranında arttırması gerekir. Etkin olan ve referans alınan ülkelere göre, yükseköğretim mezunlarının ortalama kazancını en fazla oranda arttırması gereken ülkeler, Estonya, Türkiye ve Slovakya'dır. Gözlem kümesi içerisinde yükseköğretim mezunlarının istihdam oranlarını en fazla arttırması gereken ülke ise Türkiye'dir. Analizlerin üçünde de tam etkin bulunan ülkeler, Finlandiya, İrlanda ve Slovenya'dır. Türkiye ise yapılan analizlerde son sıralarda yer almaktadır. Etkin olan bu ülkeler ile Türkiye ve diğer etkin olmayan ülkeler karşılaştırıldığında, yükseköğretime olan talebi karşılamak için yapılan yatırımların yetersiz olduğu görülmektedir. Ancak Türkiye'nin gerçekleştirdiği 5 yıllık kalkınma planları içerisinde yükseköğretime yer verilmekte ve bu doğrultuda yükseköğretimde talebin karşılanması ve yeterli kaynak sağlanması için yatırımlar yapılmaktadır.

Sonuç olarak; yükseköğretime yönelik kamu harcamalarının GSYİH içindeki payı arttırılmalı, öğrenci başına yapılan harcamalar yükseltilmelidir. Kamu kurumu tarafindan bu harcamaların karşılanmasının yetersiz kaldığı durumda, özel sektör kuruluşları veya sanayi kuruluşları ile işbirliği sağlanmalıdır. Yükseköğretim kurumlarında AR-GE faaliyetleri desteklenmelidir. Ayrıca yükseköğretim mezunlarının istihdam oranının yükseltilmesi için yeni iş kolları yaratılmalıdır. 


\section{Kaynakça}

AGASISTI, T. (2009). Performances and spending efficiency in higher education: A European comparison through non-parametric approaches. Education Economics, 19, 199224.

AKAN, Y. ve ÇALMAŞUR, G. (2011). Etkinliğin hesaplanmasında veri zarflama analizi ve stokastik sınır yaklaşımı yöntemlerinin karşılaştırılması (TRA1 alt bölgesi üzerine bir uygulama). Atatürk $\ddot{U}$. İBF Dergisi, 10. Ekonometri ve İstatistik Sempozyumu Özel Sayısı: $13-32$.

AYBARÇ BURSALIOĞLU, S. (2013). Türkiye ve AB Ülkelerinde Yükseköğretim Kamu Harcamalarının Karşılaştırmalı Etkinlik Analizi. Ankara: Gazi Kitabevi.

AYBARÇ BURSALIOĞLU S. ve Selim S. (2015). AB ülkeleri ve Türkiye'de yükseköğretimde etkinliği belirleyen faktörler. Bilig, 74, 45-69.

AYPAY, A. (2006). Üniversitelerde akademik etkinlik ve örgütsel davranış arasındaki ilişki. Kuram ve Uygulamada Ĕ̈itim Yönetimi, 46, 175-198

AYRANCI, E. (2018). Yükseköğretim hizmetlerinde etkinlik arayışları ve reformlar: Yükseköğretim sistemleri için dinamik bir veri zarflama analizi olarak MalmquistLuenberger endeksi uygulaması. Yayınlanmamış doktora tezi, Hacettepe Üniversitesi, Ankara.

BANKER, R. D., CHARNES, A. and COOPER, W. W. (1984). Some models for estimating technical and scale inefficiencies in data envelopment analysis. Management Science, 30(9), 1078-1092.

BAY, M. (2009). Bankacılık sektöründe veri zarflama analizi yöntemini kullanarak verimlilik araştırması. Yayınlanmamış doktora tezi, Selçuk Üniversitesi, Konya.

BEHDIOĞLU, S., ve ÖZCAN, G. (2009). Veri zarflama analizi ve bankacıllk sektöründe bir uygulama. Süleyman Demirel Üniversitesi İktisadi ve İdari Bilimler Fakültesi Dergisi, 14(3), 301-326.

BILDIRCIN, M. M. (2018). Eğitimde eşitlikte son işsizlikte ilk sıradayız. Birgün Gazetesi. https://www.birgun.net/haber-detay/egitimde-esitlikte-son-issizlikte-ilk-siradayiz230534.html, (08.11.2019).

CHARNES, A., W.W. COOPER, and RHODES, E. (1978). Measuring the efficiency of decision making units, European Journal of Operational Research, 2, 429-444.

CHARNES, A., COOPER, W. W. and RHODES, E. (1981). Evaluating program and managerial efficiency: an application of data envolopment analysis to program follow through. Management Science, 27(6), 668-697.

DIKMEN, F. C. (2007). Veri zarflama analizi ile üniversitelerin etkinliğinin ölçülmesi. Kocaeli Üniversitesi, Íktisadi ve İdari Bilimler Fakültesi Dergisi, 3(6), 1- 23.

DOĞRAMACI, İ. (2007). Türkiye'de ve Dünyada yükseköğretim yönetimi. Ankara: Meteksan Yayınevi

ERDEM, A. R. (2005). Üniversitenin varoluş nedeni (üniversitenin misyonu). Pamukkale Üniversitesi Eğitim Fakültesi Dergisi, 17(17), 75-86. 
ERGÜN, M. (2001). Üniversitelerde öğretim etkinliğinin geliştirilmesi. 2000 Yllında Türk Milli Ĕgitim Örgütü ve Yönetimi Ulusal Sempozyumu. Ankara: Öğretmen Hüseyin Hüsnü Tekışık Eğitim Araştırma Geliştirme Vakfı Yayınları.

GENCEL, U. (2001). Yükseköğretim hizmetlerinde toplam kalite yönetimi ve akreditasyon. Dokuz Eylül Üniversitesi Sosyal Bilimler Enstitüsü Dergisi, 3(3), 164-218.

GÜRÜZ, K. (2003). Dünyada ve Türkiye'de yüksekögrretim tarihçe ve bugünkü sevk ve idare sistemleri. Ankara. Cem Web Ofset.

GÜNER, H. ve LEVENT, A. F. (2017). Amerika, İngiltere, Kanada ve Hollanda yükseköğretim sistemlerinin incelenmesi. Ylldiz Journal of Educational Research, 2(1), 122.

GÜRAN, M. C. ve AYRANCI, E. (2019). OECD ülkelerinde yükseköğretimde etkinlik değişimi: 2000-2012 dönemi için Malmquist toplam faktör verimlilik endeksi uygulaması. Sosyoekonomi, 27(41), 71-88.

HOENACK, S. A. (1982). Pricing and efficiency in higher education. The Journal of Higher Education, 53(4), 403-418.

HAI, N., RUI, W., FANG, W. and RONGCAI, K. (2017). Research on universities' efficiency assessment based on Delphi, AHP \& DEA. 10th International Conference on Intelligent Computation Technology and Automation. 331- 335.

JAMISON, D. T. and LUMSDEN K. G. (1975). Television and efficiency in higher education. Management Science, 21(8), 920-930.

JOHNES, J. (1996). Performance assessment in higher education in Britain. European Journal of Operational Research, 89, 18-33.

JOUMADY, O. and RIS, C. (2005). Performance in European higher education: A nonparametric production frontier approach. Education Economics, 13(2), 189-205.

KANTABUTRA, S. and TANG, J. C. S. (2010). Efficiency analysis of public universities in Thailand. Tertiary Education and Management, 16(1), 15-33.

KAVAK, Y. (2011). Türkiye'de yükseköğretimin görünümü ve geleceğe bakış. Yüksekögretim ve Bilim Dergisi, 1(2), 55-58.

KAYNAR, O. (2004). Veri zarflama analizi (Data Envelopment Analysis- DEA) ve göreceli etkinlik analizi üzerine bir uygulama. Yayınlanmamış doktora tezi, Cumhuriyet Üniversitesi, Sivas.

KUAH, C. T. and WONG, K. Y. (2011). Efficiency assessment of universities through data envelopment analysis. Procedia Computer Science. 3, 499-506.

KUTLAR, A. ve BABACAN, A. (2008). Türkiye'deki kamu üniversitelerinde CCR etkinliği-ölçek etkinliği analizi: DEA tekniği uygulaması. Kocaeli Üniversitesi Sosyal Bilimler Enstitüsü Dergisi. 15(1), 148-172.

MCMILLAN, M. L. (1998). The relative efficiencies of Canadian universities: A DEA perspective. Canadian Public Policy, 24(4), 485-511.

OECD (2018). Education at a Glance 2018: OECD Indicators, OECD Publishing, Paris. http://dx.doi.org/10.1787/eag-2018-en 
ORTAŞ, İ. (2018). Bilimsel yayınlar yönünden Türkiye'nin dünyadaki yeri nedir? https://indigodergisi.com/2018/07/bilimsel-yayinlar-turkiye-yeri/

ÖZDEN, Ü. H. (2008). Veri Zarflama Analizi (VZA) İle Türkiye'deki vakıf üniversitelerinin etkinliğinin ölçülmesi. İstanbul Üniversitesi Isşletme Fakültesi Dergisi. 37(2), 167-185

SELIM, S. ve AYBARÇ BURSALIOĞLU, S. (2015). Efficiency of higher education in Turkey: A bootstrapped two-stage DEA approach. International Journal of Statistics and Applications, 5(2), 56-67.

TORRE, E. M., AGASISTI, T. and ESPARRELlS C. P. (2017). The relevance of knowledge transfers for universities' efficiency scores: An empirical approximation on The Spanish public higher education system. Research Evaluation, 26(3), 211-229.

TOTH, R. (2009). Using DEA to evaluate efficiency of higher education. Applied Studies in Agribusiness and Commerce, AGRIMBA, 4(3-4), 1-4.

TUIJMAN, A. (1990). Dilemmas of open admissions policy: Quality and efficiency in Swedish higher education. Higher Education, 20, 443-457.

TURGUTLU, T. (2006). Perakende sektöründe veri zarflama analizi ve analitik hiyerarşik proses (AHP) yaklaşımlarıyla tedarikçi performans değerlendirmesi. Yayınlanmamış yüksek lisans tezi, Dokuz Eylül Üniversitesi, İzmir.

TÜIKK (2016). Hanehalkı İşgücü Araştırması Raporu

UYAR, S. ve ALIŞ, M. (2014). Konaklama işletmelerinde veri zarflama analizi yöntemiyle faaliyet denetimi uygulaması, Dokuz Eylül Üniversitesi İktisadi ve İdari Bilimler Fakültesi Dergisi, 29 (2), 107-136.

UYSAL, D. ve AYDEMIR, E. E. (2016). Türkiye'de yükseköğretim kavramı ve yükseköğretimin istihdam ve ekonomiye etkisinin analizi. Selçuk Üniversitesi Sosyal Bilimler Enstitüsü Dergisi, 35, 275-284.

WOLSZCZAK DERLACZ, J. (2017). An Evaluation and explanation of (in) efficiency in higher education institutions in Europe and the U.S. with the application of two-stage semiparametric DEA. Research Policy, 46, 1595-1605.

YANG, G., FUKUYAMA, H. and SONG, Y. (2018). Measuring the inefficiency of chinese research universities based on a two-stage network DEA model. Journal of Informetrics, 12, $10-30$.

YÖK (2007), Türkiye'nin Yükseköğretim Stratejisi, Ankara: Meteksan A.Ş. 